NBER WORKING PAPER SERIES

FINANCIAL CHOICE IN A NON-RICARDIAN MODEL OF TRADE

\author{
Katheryn N. Russ \\ Diego Valderrama \\ Working Paper 15528 \\ http://www.nber.org/papers/w15528
}

\author{
NATIONAL BUREAU OF ECONOMIC RESEARCH \\ 1050 Massachusetts Avenue \\ Cambridge, MA 02138
}

November 2009

The authors thank Paul Bergin, Galina Hale, Bart Hobijn, and especially Martin Bodenstein for helpful discussions. Hirotaka Miura provided excellent research assistance. In addition, we are grateful to the participants at the 2009 APEA Meetings held in Santa Cruz (CA), IMF Institute, the Board of Governors of the Federal Reserve, and the University of Washington. The views expressed herein are those of the authors and do not necessarily reflect those of the Federal Reserve Bank of San Francisco, the Federal Reserve System, or the National Bureau of Economic Research.

NBER working papers are circulated for discussion and comment purposes. They have not been peerreviewed or been subject to the review by the NBER Board of Directors that accompanies official NBER publications.

(C) 2009 by Katheryn N. Russ and Diego Valderrama. All rights reserved. Short sections of text, not to exceed two paragraphs, may be quoted without explicit permission provided that full credit, including (C) notice, is given to the source. 
Financial Choice in a Non-Ricardian Model of Trade

Katheryn N. Russ and Diego Valderrama

NBER Working Paper No. 15528

November 2009

JEL No. E44,F12,F4,F41,G1

\begin{abstract}
$\underline{\text { ABSTRACT }}$
We join the new trade theory with a model of choice between bank and bond financing to show the differential effects of financial policy on the distribution of firm size, welfare, aggregate output, gains from trade, and the real exchange rate in a small open economy. Increasing bank efficiency and reducing bond transaction costs both increase welfare but have opposite effects on the extensive margin of trade, aggregate exports, and the real exchange rate. Increasing the degree of trade openness increases firms' relative demand for bond versus bank financing. We identify a financial switching channel for gains from trade where increasing access to export markets allows firms to overcome high fixed costs of bond issuance to secure a lower marginal cost of capital.
\end{abstract}

\author{
Katheryn N. Russ \\ Department of Economics \\ University of California, Davis \\ One Shields Avenue \\ Davis, CA 95616 \\ and NBER \\ knruss@ucdavis.edu \\ Diego Valderrama \\ Federal Reserve Bank of San Francisco \\ 101 Market Street \\ MS 1130 \\ San Francisco, CA 94010 \\ dv10@cornell.edu
}




\title{
Financial Choice in a Non-Ricardian Model of Trade*
}

\author{
Katheryn N. Russ ${ }^{\dagger}$ \\ University of California, Davis \\ Diego Valderrama ${ }^{\ddagger}$ \\ Federal Reserve Bank of San Francisco
}

November 2009

\begin{abstract}
We join the new trade theory with a model of choice between bank and bond financing to show the differential effects of financial policy on the distribution of firm size, welfare, aggregate output, gains from trade, and the real exchange rate in a small open economy. Increasing bank efficiency and reducing bond transaction costs both increase welfare but have opposite effects on the extensive margin of trade, aggregate exports, and the real exchange rate. Increasing the degree of trade openness increases firms' relative demand for bond versus bank financing. We identify a financial switching channel for gains from trade where increasing access to export markets allows firms to overcome high fixed costs of bond issuance to secure a lower marginal cost of capital.
\end{abstract}

\section{Introduction}

The question of how trade openness and domestic financial development interact - and how much they interact - is an important one, as domestic financial development and trade openness are favorite policy prescriptions for developing countries. ${ }^{1}$ Modern trade theory teaches that the gains from trade depend critically on a reallocation of production from small to large firms. The theory and empirics of financial development similarly demonstrate that bond market development impacts

\footnotetext{
${ }^{*}$ The authors thank Joshua Aizenman, Paul Bergin, Yu-Chin Chen, Galina Hale, Bart Hobijn, Phillip McCalman, and especially Martin Bodenstein for helpful discussions. Hirotaka Miura provided excellent research assistance. In addition, we are grateful to the participants at the 2009 APEA Meetings and seminars at the IMF Institute, Board of Governors of the Federal Reserve, University of California, Santa Cruz, and the University of Washington. The views expressed herein are those of the authors and do not necessarily reflect those of the Federal Reserve Bank of San Francisco or the Federal Reserve System.

${ }^{\dagger}$ Department of Economics, One Shields Avenue, Davis, CA 95616, USA. Email: knruss@ucdavis.edu

${ }^{\ddagger}$ Economic Research, 101 Market Street, MS 1130, San Francisco, CA 94105, USA. Telephone: +1 (415) 974-3225. Facsimile: +1 (415) 974-2168. Email: Diego.Valderrama@sf.frb.org

${ }^{1}$ Following the rash of crises in emerging markets in the late 1990 s, concerted policy efforts aiming to reduce dependence on foreign lending and bank financing in favor of domestic bond issues gained momentum among small open economies (World Bank and International Monetary Fund, 2001), most notably in the form of the Asian Bond Market Initiative. Greenspan (1999) discuss the potential benefits of developing the domestic bond market as a "spare tire" when foreign financing dries up and banks are undercapitalized. Hong Kong Monetary Authority (2001) discusses how domestic bond markets help "complete" domestic credit markets, improving risk sharing and hedging by domestic agents.
} 
firms differently according to their size. Yet the way that trade policy and specific policies aimed at credit market development interact through the reallocation of production across heterogeneous firms who can choose between financial instruments remains unexplored, with unknown implications for country welfare.

By explicitly modeling features of two different types of financial intermediaries in a model of a small open economy with heterogeneous firms, we are able to quantify the implications of financial development on firm behavior and aggregate outcomes. Existing trade models take firm choice regarding financial instruments to be exogenously determined (allowing firms to borrow in only one type of credit market) or abstract from financial frictions altogether. Previous studies analyzing how combinations of financial market imperfections impact different types of firms generally ignore their interaction with the open economy. We show that policymakers must take into account the joint effects of trade and intra-industry reallocation when evaluating the merits of policies aimed at developing specific financial markets and identify a financial switching channel that generates gains from trade openness.

In our model with financial choice, policies aimed at developing the bond market have quantitatively different implications for economic activity than policies aimed at developing the banking sector because, ultimately, they each reallocate production across firms in a unique way. Both types of policies have similar effects along certain dimensions - each increases the average capital-to-labor ratio, aggregate output, and country welfare. However, they have opposite effects on the extensive margin of trade, aggregate exports, and the real exchange rate. Further, we show that an increase in the degree of trade openness by itself can increase firms' relative demand for bond versus bank financing, even with no change in the level of transaction costs in the two credit markets. This result corresponds to the stylized fact shown in Figure1. The figure shows the growth of the ratio of domestic corporate bond issuance to domestic bank credit. Countries where exports increase compared to levels 13 or more years prior also experience growth in domestic corporate bond issues relative to domestic bank credit over the same period. In contrast, countries where exports decline experience a drop in the relative size of the bond market. In short, over long horizons countries with trend growth in exports have trend growth in the prevalence of bond issues as a source of domestic credit. ${ }^{2}$

\footnotetext{
${ }^{2}$ Specifically, we split the sample based on whether aggregate exports for each country for each year between 2002
} 
The results from our small open economy framework rest on three standard assumptions from the trade and finance literature. First, we assume that there is an endogenous number of heterogeneous, monopolistically competitive firms, as in Melitz (2003) and Ghironi and Melitz (2005). Firms combine labor and physical capital using a Cobb-Douglas technology to produce varieties of an intermediate good. Some of the firms export a portion of their output in a world market of exogenous size. Firms set prices for their unique variety based on their efficiency levels, but these individual prices have no impact on the composite world price for the intermediate good or on the aggregate price level in foreign countries. To focus on the role of firm behavior, we abstract from net capital flow considerations by assuming balanced trade in each period.

Second, we assume that these firms must borrow to finance any investment in physical capital. This borrowing prompts the third assumption: the existence of what we call financial choice. Firms can choose between bank and bond financing for their capital expenditures. We model these two credit instruments very simply as "monitored" versus "unmonitored" lending, in the tradition of the classic finance literature recently discussed in Freixas and Rochet (1997) and Baliga and Polak (2004) as well as the modern macroeconomics literature involving costly state verification, discussed in Carlstrom and Fuerst (1997) and De Fiore and Uhlig (2005). Unmonitored lending is harder to access than monitored lending but involves a lower interest rate. Thus, in our model, the fixed cost of issuing public debt (bonds) is much larger than the fixed cost involved in securing a loan.

The fixed cost of bond issuance is used to make a firm's balance sheet transparent to investors and reduces the monitoring cost. It can represent the fees charged for underwriting and commissions by investment banks that study the value of a firm's liquid assets then use their networks and expertise to inform potential bond investors so that they more easily can recover their full investment if a bond issuer defaults, though without interest. Alternatively, it can represent an insurance fee guaranteeing that investors will fully recover all assets in the event that a firm defaults. The key is that the fee reduces or eliminates monitoring costs for bond investors. Endo (2008) and Burger and Warnock (2006) find that policy actions influencing costs of domestic bond

and 2008 have increased or decreased relative to $13,14, \ldots$, or 19 years before. Then we indicate on the vertical axis the log difference in the ratio of domestic corporate bond issues to domestic bank claims during the same period (over the previous $13,14, \ldots$, or 19 years), averaging over observations in each half of the split sample. Data for exports and domestic bank claims on the private sector are from the International Monetary Fund International Financial Statistics. Data for domestic corporate (nonfinancial) bond issues are from the Bank for International Settlements online historical series. We use all countries for which there is data in all three series, for a total of 39 countries. 
issuance - including both direct regulatory fees and costs induced by regulatory uncertainty regarding whether and when an issuance can take place - are important determinants of the level of domestic bond market development. Accordingly, we choose to embody the policy stance regarding bond market development within this fixed cost. ${ }^{3}$ The smaller fixed cost of monitored bank lending makes it more easily accessible to smaller firms. Easier access comes with a higher marginal cost of financing capital, as banks must closely monitor borrowers who default, passing this higher cost on to all bank borrowers in the form of higher interest rates. In our model, this combination of financial frictions results in less efficient small firms being dependent on bank credit, while larger, more efficient firms are able to exploit the lower marginal costs of financing in the bond market. ${ }^{4}$

Policies that reduce the fixed cost of bond issuance induce firms to switch from bank borrowing to bond issuing as a source of credit, thus decreasing their marginal cost of capital since interest paid on bonds is lower than interest paid on bank loans. These switchers reduce their prices ${ }^{5}$ to capture additional domestic and external market share, which lowers the aggregate domestic price level. If these switchers were exporters before the regime change, they can export more after switching to bond purchases due to their new lower prices. Ironically, even though switchers expand their production for the domestic and overseas markets, the extensive margin shrinks for both domestic production and trade. The increased competitiveness of switchers relative to nonswitchers, combined with an increase in the real wage, owing to the combined effects of the increased demand for labor and the falling aggregate price level, pushes the very least efficient nonswitchers out of business and the least efficient nonswitching exporters out of the export market. Aggregate exports also fall. The exit of the least productive domestic producers drives the aggregate price level down a bit more than just the reduction in prices among switchers. Through its dampening effect on the domestic price level, bond market development causes the real exchange rate to depreciate.

Policies that increase the efficiency of the banking sector through measures that lower monitoring costs have a very different reallocative effect than lowering the fixed cost of bond issuance. These policies reduce the interest rates that banks charge and therefore lower marginal costs for all firms

\footnotetext{
${ }^{3}$ One might also usefully consider the overall liquidity and maturities of the issues within a bond market that impact bond yields. However, the number of participants in the bond market influence the liquidity and variety of issues and fixed costs involved in issuing bonds certainly impact the number of participants (buyers as well as issuers). We focus on the fixed cost of issuance as a first step in defining and analyzing financial choice.

${ }^{4}$ See Russ and Valderrama (2009) for a survey of the theory and evidence surrounding bank and bond financing that produced this stylized fact regarding sources of financing for small versus large firms.

${ }^{5}$ Prices are a constant markup over marginal cost in our monopolistically competitive framework.
} 
that rely on bank loans, not just for the subset of firms that switch financing sources. These bank-dependent firms lower prices and increase output. Falling interest rates on bank loans induce the marginal bond issuers to switch to bank financing. The switch reduces their fixed cost but increases their marginal cost, causing switching firms to raise their prices and lower their output. Additionally, lowering the marginal cost of bank financing induces more firms to produce for both the domestic and export markets. These additional participants are less productive than incumbent producers and exporters. Their reduced efficiency, in combination with the price increases among switchers, outweighs the effect of lower bank lending costs on the aggregate price level. As a result the aggregate price level rises, causing the real exchange rate to appreciate. At the same time, the expanded extensive margin of trade contributes to an overall increase in aggregate exports.

Considering an open economy model with endogenous financial choice and heterogeneous firms allows us to study the impact of exogenous changes in iceberg trade costs on measures of financial development in a brand new way. An change in the iceberg cost might be caused by tariff reductions; special export processing zones; or improved access to transport through investments in infrastructure, technological growth or increased competition in transport industries. A reduction in an iceberg trade cost causes a reallocation of production away from most incumbent firms toward a small subset of new entrants, firms that begin to export, and exporters who switch from bank loans to bonds because they find the lower iceberg cost increases variable profits and allows them to pay the fixed cost of bond issuance. Further, we identify this phenomenon as a financial switching channel for gains from trade where increasing access to export markets allows firms to overcome high fixed costs of bond issuance to secure a lower marginal cost of capital; this channel grows stronger when issuance costs are low.

Given our balanced trade assumption, the increase in aggregate exports means more imports, which are all intermediate goods by assumption. The increase in imported intermediates generates a complementarity in the assembly of final goods: demand increases for domestic varieties so that some new firms start to produce for the domestic market. These new firms are the smallest in the economy and use bank credit. The new bank-borrowing exporters are also small in comparison to the largest bank borrowers who suddenly switch to bond issues. Thus, reducing variable trade costs increases the ratio of bond issues to bank credit. What is more, the sectoral reallocation of production from the largest firms to smaller firms causes a real exchange rate appreciation as 
production shifts to firms with higher marginal costs (given their low efficiency) and thus higher prices.

A reduction in the fixed cost of exporting has quite different effects on financial choice and on the relative size of different financial markets. Reducing fixed barriers to export participation allows more bank borrowers to become exporters. Because the increase in production for export sale occurs only at the smaller end of the firm size distribution, there is less impact on prices and the real wage. The number of large exporting bond issuers falls just a bit due to the general equilibrium wage effect, so that aggregate exports are relatively stable. There is no complementary boost in the demand for domestic varieties to combat the second-order wage effect, so the smallest firms are forced to exit. In this case, the expansion of new exporters among bank borrowers outweighs exit at the bottom end of the size spectrum. Thus, the level of bank credit increases dramatically in comparison to the stable level of bond issues, completely opposite to the effect of lowering variable trade costs.

The following section discusses existing studies on the implications of different types of financial frictions for exporting behavior, as well as the fledgling literature examining the choice of financing instruments among firms in an open economy. Sections 3 and 4 describe the conversion of household savings into capital expenditures, as well as firm-level decisions about whether to finance

them using bank loans or bond issues and whether to export. Section 5 describes the steady-state equilibrium and discusses the calibration of the model. Section 6 discusses the results of various numerical exercises illustrating the relationship between financial market development, intra-industry reallocation, the extensive margin of trade, gains from trade liberalization, and the real exchange rate. We conclude in Section 7 with suggestions for further research.

\section{Related literature}

Relating the tradeoffs between banking sector and bond market development with trade flows in a heterogeneous firm framework crosses several segments of literature. There is a deep foundation of theoretical and empirical work analyzing the choice between banks and bonds in the closed economy, which several sources survey in detail (Freixas and Rochet, 1997, De Fiore and Uhlig, 2005, Russ and Valderrama, 2009). However, our motivating question-How does financial choice impact welfare in 
an open economy? - arises from piecing together a diverse patchwork of studies relating individual financial frictions to the pattern of trade and another very small but growing branch of literature focusing on the impacts of firms' choice between sources of financing on macroeconomic outcomes in open economies. We briefly describe the two approaches and how our work ties them together.

\subsection{Financial frictions and trade}

While we examine the impact of transaction costs and monitoring costs in credit markets on financing choice, intra-industry reallocation of production, and export decisions in a small open economy, previous studies in international trade and macroeconomics characterize financial frictions in the form of explicit credit constraints. These papers are extremely innovative and important because they rigorously characterize a link between financial development and export behavior in an empirically relevant way. At the same time, they abstract from financial choice: the lack of access to full financing is exogenously given rather than an endogenous outcome arising from transaction costs, and firms must borrow from one particular source, by assumption.

Chaney (2005) and Manova (2008) consider the impact of credit constraints on intra-industry reallocation and export decisions in models with heterogeneous firms. Chaney (2005) supposes that firms can borrow to finance fixed costs of domestic production but must generate their own liquidity - defined as domestic profits plus an exogenous endowment of fungible assets - to pay fixed costs of exporting due to incompleteness in credit markets. Some firms that could profitably export do not because they lack liquidity to enter the overseas market. The study explicitly leaves the exploration of specific vehicles for financing domestic investment open for future research, focusing instead on the interaction between the liquidity constraint and macroeconomic shocks to observe the relationship between the extensive margin of trade and the real exchange rate. Credit constraints distort the entry and exit of exporters, offering a brand new explanation for incomplete pass-through. In our model, we focus instead on basic features of two specific types of financial intermediaries to examine the interaction of trade and financial policy on the allocation of production across firms. While we do not look at short-term fluctuations arising from macroeconomic shocks, we show that small open economies experience a real depreciation if they develop their bond market by reducing issuance costs or if they subsidize bank credit or experience a real appreciation if they increase the efficiency of their banking sector in ways that reduce spread between the interests rate 
on loans and bonds. In our model, the changes in the real exchange rate occur as an endogenous outcome.

Manova (2008) assumes that heterogeneous firms must borrow to finance both fixed and variable trade costs, varying the fraction of trade costs that must be externally financed by industry. Manova enriches the model by introducing collateral, exogenously varying the degree to which externally financed purchases can be used as collateral by industry and the probability of default. In this context, the model is able to explain observed industry-level trade flows between countries with different levels of financial development. In contrast, our model involves only one industry but incorporates physical capital. We assume that all firms must finance all capital expenditures in advance using external credit, but all labor and trade costs out of cash revenues at the time of sale. All firms have, in principle, access to both types of financing, bonds and loans. However, depending on the firm-specific efficiency level, each firm chooses to finance either through bank loans or by issuing bonds. The degree to which capital expenditures serve as collateral varies by the type of financial intermediary, rather than by industry. In bond markets, a large issuance cost is used to broadcast information about the firm that reduces or eliminates monitoring costs for bondholders when firms default, allowing them to recoup borrowed capital with little or no loss of principal. Banks, on the other hand, must go through costly proceedings to audit and press the fraction of firms that default for repayment, burning up a larger fraction of borrowers' collateralized capital holdings in the form of monitoring costs. Firms that choose to finance through bank loans pay this cost in the form of higher interest rates, resulting in higher marginal costs of capital that make them less able to export. Our aim is to contrast the impact of altering the relative attractiveness of these two different types of financial instruments on aggregate outcomes in a small open economy.

In addition to the contributions of Chaney (2005) and Manova (2008), a rich literature holds that there is a recursive relationship between comparative advantage and domestic financial development. Antràs and Caballero (2009) introduce financial frictions in a Heckscher-Ohlin/MundellVanek framework to show that, in financially underdeveloped countries, trade and capital flows can be complements rather than substitutes, in contrast to the traditional capital-flows approach established by Mundell (1957). ${ }^{6}$ The authors allow for capital mobility across countries and also

\footnotetext{
6 Antràs and Caballero $(2009)$ note a new generation of theoretical contributions beginning with the seminal work of Bardhan and Kletzer (1987), with the most recent empirical support for the link between financial development and comparative advantage provided by Manova (2008). We refer the reader to their comprehensive survey of financial
} 
model financial frictions as an exogenous credit constraint - a refusal on the part of intermediaries to lend quite as much to producers as they need to purchase the optimal level of capital for production. The degree of financial development influences the degree of comparative advantage and trade patterns. We abstract from international capital flows in our model to focus on the structure of specific domestic financial institutions - banks and bond markets - showing that they have different effects on the capital-to-labor ratio (the driving source of comparative advantage in Ricardian models), welfare, and the extensive margin of trade.

In a contrasting approach, Do and Levchenko (2007) suggest that the degree of comparative advantage and pattern of trade can influence a country's level of financial development, rather than viceversa. They provide empirical evidence that specialization in industries requiring more external finance promotes more developed financial markets. Our model captures their finding that that trade flows can drive financial development, measured by the ratio of total private credit to gross domestic product (GDP).

\subsection{Firm financing decisions in the open (macro) economy}

Razin and Sadka (2007) and Smith and Valderrama (2009) are two recent theoretical contributions that analyze the macroeconomic consequences of financing choice in an open economy setting. Both of these papers focus on the impact that financing choice has on macroeconomic outcomes, particularly on the composition of aggregate capital flows. ${ }^{7}$ Razin and Sadka (2007) consider the impact of two forms of firm financing for capital investment, foreign direct investment (FDI) and portfolio investment, on aggregate capital flows while allowing for firm heterogeneity. The key mechanism of their model lies in sensitivity of heterogeneous investors, who make the key financial choices, to liquidity shocks. Countries with greater macroeconomic volatility attract investors who are less sensitive to liquidity shocks and attract less-reversible FDI, while countries that are more prone to liquidity shocks attract investors who prefer more-reversible portfolio investment. FDI reveals more information about the firm, so that firms that attract FDI optimally adjustment their capital stock and grow more. Thus, financial choice by investors has important consequences for the aggregate capital stock, as well as the overall balance of FDI and portfolio flows in a frictions and comparative advantage.

${ }^{7}$ See Russ (2009) for a discussion of the split between the study of firm financing decisions (with a focus on foreign direct investment) and the study of trade and capital flows. 
country's financial account. We consider financial choice from the perspective of the firm and the intermediary, rather than the investor. The gap is fertile ground for future research. ${ }^{8}$

Smith and Valderrama (2009) use a structural model to show that the choice of financing (by selling the firm via FDI, issuing additional equity shares, or borrow using bonds) by a representative firm can influence the properties of the real business cycle in small open economies. In contrast to Razin and Sadka (2007) and Smith and Valderrama (2009), we do not study the role that firm financing decisions have on capital flows. We focus instead on the role that domestic financial imperfections have on the steady-state level of financial development, production reallocation, export decisions, and the real exchange rate. Most firms in emerging markets do not have access to foreign capital markets, so we view our focus on domestic financial institutions as the most relevant to study the impact of financial frictions across the entire spectrum of firms operating in an economy.

Levchenko, Rancière, and Thoenig (2009) provide empirical evidence using industry-level data that increased access to credit following financial liberalization increases firm entry, employment, and capital investment, leading to a positive aggregate growth effect. However, due to data constraints it is not clear exactly which features of the institutional change are driving the change in firm behavior, or if different types of financial development impact firm behavior differently. Our model can rationalize some of the findings in Levchenko, Rancière, and Thoenig (2009) while establishing causal relationships between a reduction in financial frictions and endogenous outcomes - intraindustry reallocation; firm decisions regarding entry, investment, and employment; and aggregate output.

\section{Savings and investment}

In the model introduced here, savings by consumers are transformed into funds for capital through two forms of domestic financial intermediaries, banks and bond underwriters. The emphasis of the study is on the impact of financial imperfections on the decisions by firms about borrowing, production, and export decisions and macroeconomic aggregates. Households provide important inputs to production through their supply of inputs to firms via savings and labor, and their consumption and welfare are determined endogenously. This section describes the problem of

\footnotetext{
${ }^{8}$ For instance, see Fillat and Garreto (2009) for empirical evidence relating fluctuations in equity values to firms' decisions to invest in global markets as multinationals versus domestically as exporters.
} 
the representative household and financial intermediaries, while Section 4 describes the financial, production, and export decisions by firms.

\subsection{Households}

The representative consumer maximizes lifetime utility,

$$
\max _{C_{t}, L_{t}, K_{t+1}^{S}} \sum_{t=0}^{\infty} \beta^{t} U\left(C_{t}, L_{t}\right)
$$

where

$$
U\left(C_{t}, L_{t}\right)=\frac{1}{1-\eta}\left(C_{t}-\frac{L_{t}^{\psi}}{\psi}\right)^{1-\eta}
$$

and $C_{t}$ and $L_{t}$ represent aggregate consumption and the labor supply in period $t$.

The consumer maximizes utility subject to an intertemporal budget constraint,

$$
P_{t} Y_{t}=P_{t} C_{t}+P_{t} K_{t+1}=w_{t} L_{t}+r_{t} P_{t} K_{t}+(1-\gamma) P_{t} K_{t}+\pi_{t}^{I}+\pi_{t}^{F}
$$

with $P_{t}$ being the aggregate price level and $\pi_{t}^{F}$ and $\pi_{t}^{I}$ representing firm profits and fees charged by financial intermediaries which are paid back in the form of dividends to the consumer. Units of aggregate output, $Y_{t}$, can be devoted either to consumption or to savings. The term $K_{t+1}$ denotes consumer savings from period $t$ income transformed into capital expenditures for use in period $t+1$. The representative consumer receives a return of $r_{t}$ on each unit of capital set aside for the next period, regardless of whether the savings are in the form of bank deposits or corporate bonds. ${ }^{9}$ Capital depreciates at rate $\gamma$.

In steady state, the relevant results from the consumer's first-order conditions are equations that determine the labor supply as a function of the real wage rate alone and the gross rate of

\footnotetext{
${ }^{9}$ We will explain below that the risk-adjusted return on both assets must be equal to eliminate any arbitrage opportunity. We assume that bond underwriters assume the risk of default on bonds to streamline notation (using only one rate of return on savings) in the consumer's problem, but we could achieve an observationally equivalent steady-state result by transferring the risk to consumers and specifying a separate rate of return for household bond holdings versus bank deposits, which are riskless. In reality, underwriters conducting a primary issue do assume significant risk between the time they purchase bonds from firms and sell them to investors.
} 
return on savings being pinned down by the consumer's discount factor and the depreciation rate:

$$
\begin{aligned}
L & =\left(\frac{w}{P}\right)^{\left(\frac{1}{\psi-1}\right)} \quad \text { and } \\
1+r & =\frac{1}{\beta}+\gamma
\end{aligned}
$$

respectively.

\section{$3.2 \quad$ Financial intermediaries}

The corporate finance literature focuses on two salient features when contrasting banks and bond markets as sources of funds for capital expenditures: large bond issuance costs and high interest rates on bank loans. A number of authors explain that high bond issuance costs are necessary to disseminate information regarding firms' balance sheets to potential investors. Others posit that special relationships between banks and firms arise to surmount problems of asymmetric information. Overcoming the asymmetric information problem can lead to higher interest rates on bank loans for two reasons. It can make it costly for customers to develop a relationship with a new lender, engendering monopoly power among bank managers. Alternatively, it can force a bank to "monitor" some borrowers to make sure they repay their loans, even in a perfectly competitive market for bank credit. These monitoring costs are also referred to as "costly state verification"—if a borrower defaults, a bank incurs costs to audit the borrower, sue, or liquidate the borrower's assets to recover accounts payable. We assume that large issuance costs make the monitoring cost lower for bondholders than for banks.

We incorporate these two features in the simplest way possible to focus on the intuition behind the impacts the two types of financing can have on firm behavior in an open economy. To finance capital expenditures using bonds, a firm must pay a large fixed cost, $\tilde{f}_{b}=\left(1+r_{b}\right) f_{b} \cdot{ }^{10}$ We assume that this fixed cost makes the firm transparent to investors from the time of issue, with little or no monitoring necessary. It is sufficient that the monitoring cost for bonds merely be lower than that for bank loans. Without loss of generality, we assume it is zero for simplicity. In our stylized setup,

\footnotetext{
${ }^{10}$ We assume that creditors "front" borrowers this fixed cost, $\tilde{f}_{b}$, which is paid with interest at the end of the period. This corresponds to the practice of underwriters including fees as part of the "gross spread" between the price at which they purchase bonds from firms and the price at which they sell the bonds to investors. For consistency, we model the fixed cost of bank loans the same way, as though closing costs and other fees are included in the loan principal.
} 
this "unmonitored" lending means that even if a firm tries to default, bondholders have information that allows them to costlessly seize and liquidate all of the firm's capital holdings without any of the difficulties involved in audits and bankruptcy proceedings faced by banks. The primary risk posed by default in this case is that they receive no interest on the borrowed capital. Thus, bond yields $r_{b}$ are equal to the steady-state interest rate shown in equation (3.3), adjusted for the risk of default: $r_{b}=\frac{r}{1-\delta} \cdot 11$ We assume that underwriters assume the entire risk of default between the time they purchase bond issues from firms and sell them to households to simplify the exposition of the consumer's problem, but the result is observationally equivalent in steady state when consumers bear the risk instead of underwriters, as they will still demand the same risk-adjusted interest rate, $r_{b}$

Obtaining a bank loan incurs a smaller fixed cost than bond issuance: $\tilde{f}_{l}=\left(1+r_{b}\right) f_{l}$, with $\tilde{f}_{l}<\tilde{f}_{b}$. The interest rate banks charge on loans include an extra markup over the deposit rate $r$ to cover costly state verification for a fraction of firms that try to default. Define $\delta$ as the fraction of firms that receive an exogenous forced exit shock and try to default on their loans. ${ }^{12}$ The exit shock does not destroy capital holdings, but makes the firm unable to produce. In our model, it does not matter if the default rate is lower for bond issuers, as seen in Diamond (1991) and related models, because it still results in a bond yield that is lower than the interest rate on bank loans. We assume that $\delta$ is equal across firms for simplicity and to align it with existing models of heterogeneous firms in open economies. Suppose that banks have to pay some fraction, $\mu$, of the total amount of their loans to defaulting firms in order to recover the firms' borrowed capital holdings. For simplicity (and without loss of generality) we assume that the monitoring cost for bondholders is equal to zero. Then banks must charge an interest rate at least high enough to cover expected monitoring costs, generating a spread between the interest rates that banks charge on loans, $r_{l}$, and the bond yield. If banks are perfectly competitive, then this spread is a function of the monitoring cost and the default rate: ${ }^{13}$

$$
r_{l}=r_{b}+\frac{\delta \mu}{1-\delta}
$$

\footnotetext{
${ }^{11}$ See Appendix A for derivation.

${ }^{12}$ This forced exit shock is drawn from Melitz $(2003)$ and is equal to the net exit rate in steady state. The exit rate involving plant closings in Dunne, Roberts, and Samuelson (1988) (8.7-17.3 percent for new plants, 1.1-2.2 percent for established plants) is similar to the default rates surveyed by Russ and Valderrama (2009).

${ }^{13}$ See Appendix A for derivation.
} 
It follows that the marginal costs for firms financing capital expenditures using bank loans will always be higher than marginal costs for firms financing capital expenditures using bond issues.

\section{$4 \quad$ Firms}

In this section we describe the problem faced by firms. Final goods are produced by competitive firms using both domestically produced and imported intermediate goods. The focus of our study is on the domestic intermediate goods producers. These producers are imperfectly competitive and take the wage rate, the interest rate (for bonds or loans), and the fixed costs of financing and exporting as given. They produce using a constant-returns-to-scale technology. Individual firms observe their idiosyncratic level of efficiency before making financing, production, and export decisions. In equilibrium, depending on its level of efficiency, each firm elects to produce domestically if its expected profits are high enough to cover the costs of production and financing. We show that under a very mild assumption supported by data on interest rates and fixed costs of financing, the marginal active firm will be a bank borrower, while firms with very high levels of efficiency will borrow by issuing bonds. This result corresponds with the stylized fact in the finance literature that bond issuers tend to be larger than bank borrowers.

Firms must pay an additional fixed cost before entering the export market. Thus, it is easy to show that exporting firms always serve the domestic market, though not all firms that serve the domestic market also export. Depending on the relative cost of capital, the wage rate, and the different fixed costs, it is possible that the marginal exporter is a bank borrower or a bond issuer. Below, we show the conditions under which the marginal exporter is a bank borrower (the case we consider most plausible) and focus on this case in the numerical exercises. If the marginal exporter is a bank borrower, then it can be shown that all bond issuers will produce both for the domestic market and also export. 


\subsection{Demand for differentiated intermediate inputs}

In the small open economy, production of the final good, $Y$, takes place in-country but requires a continuum of intermediate inputs, both domestically produced and imported:

$$
Y=\left(y_{d}^{\frac{\varepsilon-1}{\varepsilon}}+y_{m}^{\frac{\varepsilon-1}{\varepsilon}}\right)^{\frac{\varepsilon}{\varepsilon-1}}
$$

where $\varepsilon>1, y_{d}$ represents the bundle of domestic goods, and $y_{m}$ represents the imported bundle. For simplicity, we assume the imported bundle is a standardized unit and do not consider increasing or decreasing varieties of imports. We focus instead on the domestic bundle, with an endogenous number of varieties produced by both bank borrowers (denoted by the subscript $l$ for loans) and bond issuers (denoted $b$ for bonds).

The assembly by final goods producers using CES technology yields the small country's demand for domestic varieties from sector $j(j \in\{l, b\})$ and imported goods, ${ }^{14}$

$$
\begin{aligned}
y_{j d}(\varphi) & =\left(\frac{p_{j}(\varphi)}{p_{d}}\right)^{-\sigma}\left(\frac{p_{d}}{P}\right)^{-\varepsilon} Y \\
y_{m} & =\left(\frac{p_{m}}{P}\right)^{-\varepsilon} Y .
\end{aligned}
$$

Domestically produced intermediate goods are all tradable, but not necessarily traded in equilibrium.

$P$ is the domestic price level,

$$
P=\left[\left(p_{d}^{1-\varepsilon}\right)+\left(p_{m}^{1-\varepsilon}\right)\right]^{\frac{1}{1-\varepsilon}}
$$

By definition, the small open economy's production decisions have no impact on the price of goods produced abroad, or on aggregate price levels (for aggregate imports or final goods) in foreign countries. We normalize the price of all foreign-produced goods and any foreign price indexes to equal 1 , or $p_{m} \equiv p_{m}^{*} \equiv P^{*} \equiv 1$.

Each home firm has the option of exporting if it pays a fixed cost, $P^{*} f_{x}$ (a distribution cost denominated in terms of foreign consumption units). We assume that the foreign demand function

\footnotetext{
${ }^{14}$ Recall that we abstract from any complexities involving individual foreign firms' efficiency levels and treat all imported goods as identical and the number of imported varieties (though not the quantities) as fixed.
} 
for the small open economy's exports from sector $j$, given an iceberg trade cost $\tau>1$, takes the following form

$$
y_{j x}(\varphi)=\left(\tau p_{j}(\varphi)\right)^{-\sigma} Y^{*}
$$

For the small open economy, $Y^{*}$ is treated as exogenous.

\subsection{Domestic production and assembly of intermediate goods}

Each firm produces a unique variety of an intermediate good subject to an individual efficiency parameter, $\varphi$, drawn from the cumulative distribution $H(\varphi)$. All firms use a Cobb-Douglas technology,

$$
y_{j k}(\varphi)=\varphi A L_{j k}(\varphi)^{\alpha} K_{j k}(\varphi)^{1-\alpha}
$$

with $\alpha<1, k \in\{d, x\}$. The subscript $d$ denotes domestic production and $x$ denotes export production.

Given the firm production technology, we derive the cost-minimizing input demand functions,

$$
\begin{aligned}
L_{j k}^{*}(\varphi) & =\left[\left(\frac{1-\alpha}{\alpha}\right) \frac{w}{r_{j}}\right]^{\alpha-1} \frac{y_{j k}(\varphi)}{A \varphi} \\
K_{j k}^{*}(\varphi) & =\left[\left(\frac{1-\alpha}{\alpha}\right) \frac{w}{r_{j}}\right]^{\alpha} \frac{y_{j k}(\varphi)}{A \varphi}
\end{aligned}
$$

where $w$ is the wage and $r_{j}$ is the cost of capital. The cost of capital varies according to whether firms use bank loans or bond issues to finance their capital expenditures. For simplicity, we assume that the capital expenditures must be refinanced each period. As in Melitz (2003), there is an endogenously determined mass of entrants, $n$, of which a subset, $n_{l}$, decides to use bank credit and another subset, $n_{b}$, issues bonds to finance expenditures on capital. Some $\left(n_{l x}\right)$ bank borrowers and some bond issuers $\left(n_{b x}\right)$ also decide to export.

Final goods producers assemble domestically produced varieties using a constant elasticity of substitution (CES) technology:

$y_{d}=\left(\frac{1}{H\left(\varphi_{b d}\right)-H\left(\varphi_{l d}\right)} \int_{0}^{n_{l d}} \int_{\varphi_{l d}}^{\varphi_{b d}} y_{l d}(\varphi)^{\frac{\sigma-1}{\sigma}} d H(\varphi) d i+\frac{1}{1-H\left(\varphi_{b d}\right)} \int_{n_{l d}}^{n_{b d}} \int_{\varphi_{b d}}^{\infty} y_{b d}(\varphi)^{\frac{\sigma-1}{\sigma}} d H(\varphi) d i\right)^{\frac{\sigma}{\sigma-1}}$, 
where $\sigma>1$. In this expression, we use the result shown later that bank borrowers have idiosyncratic productivity in the interval $\left[\varphi_{l d}, \varphi_{b d}\right)$, and bond issuers have productivity in the interval $\left[\varphi_{b d}, \infty\right)$.

The price index for the bundle of domestically produced and consumed goods is then

$$
p_{d}=\frac{\sigma}{\sigma-1} \frac{w^{\alpha}}{(1-\alpha)^{1-\alpha \cdot \alpha^{\alpha} A \bar{\varphi}}}
$$

The aggregate productivity level for domestically consumed home production, $\bar{\varphi}$, is defined in terms of the average productivity level among bank borrowers, $\bar{\varphi}_{l d}$, and bond issuers, $\bar{\varphi}_{l d}$, as

$$
\bar{\varphi}=\left(n_{l d} r_{l}^{-(1-\alpha)(\sigma-1)} \bar{\varphi}_{l d}^{\sigma-1}+n_{b d} r_{b}^{-(1-\alpha)(\sigma-1)} \bar{\varphi}_{b d}^{\sigma-1}\right)^{\frac{1}{\sigma-1}}
$$

The sectoral efficiency levels among bank borrowers and bond issuers are then

$$
\begin{aligned}
\bar{\varphi}_{l d}^{\sigma-1} & \equiv \frac{1}{H\left(\varphi_{b d}\right)-H\left(\varphi_{l d}\right)} \int_{\varphi_{l d}}^{\varphi_{b d}} \varphi^{\sigma-1} d H(\varphi) \quad \text { and } \\
\bar{\varphi}_{b d}^{\sigma-1} & \equiv \frac{1}{1-H\left(\varphi_{b d}\right)} \int_{\varphi_{b d}}^{\infty} \varphi^{\sigma-1} d H(\varphi)
\end{aligned}
$$

respectively.

\subsection{The marginal firm}

After deciding whether to become active, firms draw their efficiency level and then decide whether to produce or export. Firms earn profits from domestic sales:

$$
\pi_{j d}(\varphi)=\frac{1}{\sigma}\left(\frac{p_{j}(\varphi)}{p_{d}}\right)^{1-\sigma}\left(\frac{p_{d}}{P}\right)^{1-\varepsilon} P Y-P \tilde{f}_{j} \quad j \in\{l, b\}
$$

A firm will not be active at all unless it is at least sufficiently productive to serve the domestic market without losing money. Thus, there is a participation constraint for domestic production,

$$
\pi_{j d}\left(\varphi_{j d}\right) \equiv 0
$$

It is straightforward to show that this marginal participant will be a bank borrower as long as 
the gap ratio of the fixed cost of bond issues and bank borrowing is sufficiently large relative to the ratio of the interest rates associated with bank and bond credit. ${ }^{15}$ More specifically, the marginal participant is a bank borrower as long as the following condition holds:

$$
\frac{\tilde{f}_{b}}{\tilde{f}_{l}}>\left(\frac{r_{l}}{r_{b}}\right)^{(1-\alpha)(\sigma-1)}
$$

The condition requires that the marginal cost advantage of bond financing is large enough that any firm sufficiently profitable to pay the fixed cost of issuance with do so. Taking the ratio of the average prime rate and average Moody's Seasoned Aaa bond yield from January 1949 through July 2007, this condition requires that the fixed cost of bond issues be only 1-10 percent higher than the fixed cost of securing bank credit for standard parameterizations of $\alpha$ and $\sigma$, well within the range observed in the data. In our simulations, we assume that this condition holds, so that profits for the marginal bank borrower are zero:

$$
\pi_{l d}\left(\varphi_{l d}\right) \equiv 0
$$

Equation 4.11 pins down the value of the efficiency level for the marginal bank-borrowing producer, $\varphi_{l d}$.

\subsection{The marginal exporter}

If a firm pays an additional fixed export cost, $f_{x}$, it can earn profit from export sales to the rest of the world,

$$
\pi_{j x}(\varphi)=\frac{\tau^{-\sigma}}{\sigma}\left(p_{j}(\varphi)\right)^{1-\sigma} Y^{*}-P \tilde{f}_{x}
$$

Because the firm knows how efficient it is before deciding to export and because exporting requires an additional fixed cost, any firm that exports also serves the domestic market. Therefore, we express total profit for the individual firm as

$$
\pi_{j}^{T}(\varphi)=\max \left[0, \pi_{j d}(\varphi)+\max \left\{0, \pi_{j x}(\varphi)\right\}\right]
$$

\footnotetext{
${ }^{15}$ The sufficient condition for this marginal domestic producer to be a bank borrower requires only that the domestic profit equation be steeper for a bond issuer than for a bank borrower and that the domestic profit functions of the two are equal where profits are greater than zero. See Russ and Valderrama (2009) for a detailed discussion.
} 
The additional profit that the least efficient exporter earns from export sales must be zero. If it were higher, then more firms would export. If it were lower, then some firms would quit exporting. In the same manner as equation (4.11), we can derive the following condition for the marginal exporter, which might be a bank borrower or a bond issuer:

$$
\pi_{j x}\left(\varphi_{j x}\right) \equiv 0
$$

where $\varphi_{j x}$ is the efficiency level of the marginal exporter.

\subsection{The marginal bond issuer}

Suppose that at least one bank borrower exports. Given the assumption in equation (4.10), guaranteeing that the most efficient firms are bond issuers and the least efficient are bank borrowers, it is then straightforward to prove that if the fixed cost of exporting is low enough to permit any bank borrower to export, all bond issuers will also export. ${ }^{16}$ The intuition is simple: Let $\varphi_{b x}$ represent the efficiency level of the marginal bond issuer that exports. Satisfying the condition in equation (4.10) allows us to identify the efficiency level of the marginal bond issuer, $\varphi_{b d}=\varphi_{b x}$, as the point where profits for exporting bank borrowers and exporting bond issuers are equal. Because profits are increasing in $\varphi$ and marginal costs are lower for bond issuers, all firms that are more efficient than the firm associated with $\varphi_{b x}$ also finance their capital expenditures by issuing bonds.

With this in mind, the bond market participation condition in this case is

$$
\pi_{b}^{T}\left(\varphi_{b x}\right) \equiv \pi_{l}^{T}\left(\varphi_{l x}\right)
$$

A bit of algebra reveals the second necessary condition for some bank borrowers to export:

$$
\frac{\varphi_{b x}}{\varphi_{l x}}=\left[\frac{\tilde{f}_{b}-\tilde{f}_{l}}{\tilde{f}_{l}+f_{x}} \cdot \frac{r_{l}^{(1-\alpha)(1-\sigma)}}{r_{b}^{(1-\alpha)(1-\sigma)}-r_{l}^{(1-\alpha)(1-\sigma)}} \cdot\left(1+\frac{p_{d}^{\sigma-\varepsilon} P^{\varepsilon} Y}{\tau^{(-\sigma)} Y^{*}}\right)\right]^{(1 /(\sigma-1))}>1
$$

For bank borrowing and bond issuing exporters to coexist, the fixed cost of bond issuance must be big relative to the gap between the interest rate on bank loans and the bond yield.

\footnotetext{
${ }^{16}$ See Appendix B for proof. We could alternatively say that whenever equation 4.10 holds, if any exporter issues bonds, then all bond issuers export.
} 
Do all firms export? Not necessarily. Dividing the $\varphi_{x l}$ by $\varphi_{l}$ obtained from equations 4.12 and 4.11, we derive the efficiency level of the marginal exporter as a function of the efficiency level of the least productive firm that serves the domestic market:

$$
\varphi_{l x}=\left[\left(\frac{\tilde{f}_{l}+f_{x}}{\tilde{f}_{l}}\right)\left(\frac{p_{d}^{\sigma-\varepsilon} P^{\varepsilon} Y}{\tau^{-\sigma} Y^{*}}\right)\right]^{\left(\frac{1}{\sigma-1}\right)} \varphi_{l d} .
$$

Nontraded goods exist whenever $\varphi_{l x}>\varphi_{l d}$. The intuition is clear: there are nontraded goods whenever the fixed cost of exporting is large enough relative to the fixed cost of securing bank credit and the degree of domestic absorption is sufficiently high that it is worthwhile to produce even if a firm cannot export.

If the condition in equation (4.14) does not hold then the marginal exporter is a bond issuer and we need only solve for $\varphi_{l d}, \varphi_{b d}$, and $\varphi_{b x}$. In this case, equation 4.15) becomes

$$
\varphi_{b x}=\left[\left(\frac{r_{b}}{r_{l}}\right)^{(1-\alpha)}\left(\frac{\tilde{f}_{b}+f_{x}}{\tilde{f}_{l}}\right)\left(\frac{p_{d}^{\sigma-\varepsilon} P^{\varepsilon} Y}{\tau^{-\sigma} Y^{*}}\right)\right]^{\left(\frac{1}{\sigma-1}\right)} \varphi_{l d}
$$

\section{$5 \quad$ Solving the model}

To solve for the steady-state equilibrium, we begin with the steady-state version of the goods market clearing condition,

$$
P Y=P C+P I+N X=P C+\gamma P K+N X
$$

where $N X$ represents net exports.

Given our balanced trade assumption, the steady-state version of the consumer's budget constraint, equation (3.1), becomes

$$
P Y=w L+\left(1+r_{b}-\gamma\right) P K+\Pi^{F}+\Pi^{I}
$$

where $\Pi^{F}$ and $\Pi^{I}$ are aggregate profits remitted by firms and financial intermediaries. We assume here that all fixed costs (bond issuance, bank borrowing, and export) are returned in lump sum dividends to the consumer. 


\subsection{Aggregation}

Aggregate demand for labor, $L^{D}$, and capital, $K^{D}$ can be expressed in terms of the average productivity level in each sector given by ${ }^{17}$

$$
\begin{aligned}
L^{D} & =(1-\delta)\left[n_{l} L_{l d}\left(\bar{\varphi}_{l d}\right)+n_{l x} L_{l x}\left(\bar{\varphi}_{l x}\right)+n_{b x} L_{b d}\left(\bar{\varphi}_{b x}\right)+n_{b x} L_{b x}\left(\bar{\varphi}_{b x}\right)\right] \\
K^{D} & =n_{l} K_{l d}\left(\bar{\varphi}_{l d}\right)+n_{l x} K_{l x}\left(\bar{\varphi}_{l x}\right)+n_{b} K_{b d}\left(\bar{\varphi}_{b x}\right)+n_{b x} K_{b x}\left(\bar{\varphi}_{b x}\right) .
\end{aligned}
$$

Note that firms hit by the exit shock do not hire labor, so we eliminate their "would-be" labor demand from the aggregate equation. The exit shock does not destroy capital, just prevents capital from being used for production, so the shock does not directly enter into the formula for the aggregate capital stock. Total labor demand (5.2) is equal to the sum of labor demand by bank borrowers that only produce domestically $\left(n_{l}\right)$, bank borrowers that export $\left(n_{l x}\right)$, and bond issuers that also export $\left(n_{b x}\right)$. The expressions on the right-hand side of equation $(5.2)$ are simply functions of the output-weighted average productivity levels for each sector, the wage rate, and the interest rate. Analogously, total capital demand (5.3) is the sum of the capital demands by the three types of producers.

To obtain the right-hand side terms for the two demand expressions, we use the result that all bond issuers are also exporters (i.e. $\varphi_{b d}=\varphi_{b x}$ and $n_{b x}=\left(1-H\left(\varphi_{b x}\right)\right) n$ ) so that we can rename the average productivity level for all bond issuers from equation $(4.9)\left(\bar{\varphi}_{b d}=\bar{\varphi}_{b x}\right)$. For bank borrowers, we have firms that only produce domestically $\left(n_{l d}=\left(H\left(\varphi_{b x}\right)-H\left(\varphi_{l d}\right)\right) n\right)$ and firms that also export $\left(n_{l d}=\left(H\left(\varphi_{b x}\right)-H\left(\varphi_{l x}\right)\right) n\right)$. The average productivity levels for bank borrowers producing for the home and export market are as follows:

$$
\begin{gathered}
\bar{\varphi}_{l d}^{\sigma-1} \equiv \frac{1}{H\left(\varphi_{l x}\right)-H\left(\varphi_{l d}\right)} \int_{\varphi_{l d}}^{\varphi_{l x}} \varphi^{\sigma-1} d H(\varphi) \quad \text { and } \\
\bar{\varphi}_{l x}^{\sigma-1} \equiv \frac{1}{H\left(\varphi_{b x}\right)-H\left(\varphi_{l x}\right)} \int_{\varphi_{l x}}^{\varphi_{b x}} \varphi^{\sigma-1} d H(\varphi)
\end{gathered}
$$

Labor supply is obtained from the steady-state version of the labor first-order condition 3.2 .

\footnotetext{
${ }^{17}$ Note that in the case where there is at least one bank borrower exporting, all bond issuers serve both the domestic and export market, so $n_{b}=n_{b x}$. Derivations for the aggregation are located in the appendix.
} 
The supply of capital is determined by the condition that relates the domestic interest rate, $r$, to the consumer's rate of time preference, $\beta$, given in equation (3.3). In equilibrium, the demand for capital must equal the supply of capital $\left(K^{D}=K^{S}\right)$, and the demand for labor must equal the supply of labor $\left(L^{D}=L^{S}\right)$ :

We aggregate the profits of all firms as a function of the average productivity level in each sector and aggregate all fees collected by intermediaries:

$$
\begin{aligned}
\Pi^{F} & =(1-\delta)\left[n_{l d} \pi_{l d}\left(\bar{\varphi}_{l d}\right)+n_{l x} \pi_{l x}\left(\bar{\varphi}_{l x}\right)+n_{b x} \pi_{b x}^{T}\left(\bar{\varphi}_{b x}\right)\right] \\
\Pi^{I} & =P\left[\left(n_{l} \tilde{f}_{l}+n_{b x} \tilde{f}_{b}+n_{e} f_{e}+n_{b x} f_{x}\right)(1+\delta)+\mu \delta K^{D}\right],
\end{aligned}
$$

where the average productivity level for all bank borrowers $\bar{\varphi}_{l d}$ is given by equation 4.8.

As in Melitz (2003), we use a free entry condition to determine the number of firms in steady state and assume that firm managers are risk-neutral. Let $\bar{\pi}^{T}$ denote average total profit per firm. We show in the appendix that ex ante, average profits are given by

$$
\bar{\pi}^{T}=\frac{n_{l d}}{n} \pi_{l d}\left(\bar{\varphi}_{l d}\right)+\frac{n_{l x}}{n} \pi_{l x}\left(\bar{\varphi}_{l x}\right)+\frac{n_{b x}}{n} \pi_{b d}\left(\bar{\varphi}_{b x}\right)+\frac{n_{b x}}{n} \pi_{b x}\left(\bar{\varphi}_{b x}\right) .
$$

Discounting by the probability of a forced exit shock in each period, $\delta$, yields a simple expression for the present discounted value of all future profits, which must equal the fixed entry fee, $f_{e}$, in equilibrium:

$$
\begin{aligned}
\left(\frac{1}{1-\beta(1-\delta)}\right) \bar{\pi}^{T} & \equiv P f_{e} \\
\bar{\pi}^{T} & =[1-\beta(1-\delta)] P f_{e} .
\end{aligned}
$$

In steady state, it is straightforward to show that the total value of expenditures (revenues) $P Y$ equals the total number of firms $n$ times average firm revenues $\rho(P \times Y=n \rho)$. Profits and revenues are related as follows

$$
\pi_{j k}(\varphi)=\frac{\rho_{j k}(\varphi)}{\sigma}-P \tilde{f}_{j}
$$

where $\rho_{j k}=p_{j}(\varphi) y_{j k}(\varphi), j \in\{b, l\}$, and $k \in\{d, x\}$. Thus, we can obtain an expression for the 
number of firms, $n$ as a function of total revenues and the average per-firm revenue:

$$
\begin{aligned}
n & =\frac{P Y}{\bar{\rho}} \\
& =\frac{P Y}{\sigma(1-\delta)\left(\frac{\bar{\pi}^{T}}{1-\delta}+\frac{n_{l d}+n_{l x}}{n} P \tilde{f}_{l}+\frac{n_{b x}}{n} P \tilde{f}_{b}+\frac{n_{l x}+n_{b x}}{n} P f_{x}\right)} .
\end{aligned}
$$

Substituting $\bar{\pi}$ from equation (5.4) into equation (5.5) yields

$$
\begin{aligned}
n & =\frac{P Y}{\sigma(1-\delta)\left\{\frac{[1-\beta(1-\delta)] P f_{e}}{1-\delta}+\frac{n_{l d}+n_{l x}}{n} P \tilde{f}_{l}+\frac{n_{b x}}{n} P \tilde{f}_{b}+\frac{n_{l x}+n_{b x}}{n} P f_{x}\right\}} \\
& =\frac{Y}{\sigma(1-\delta)\left\{\frac{[1-\beta(1-\delta)] f_{e}}{1-\delta}+\left[H\left(\varphi_{b x}\right)-H\left(\varphi_{l}\right)\right] \tilde{f}_{l}+\left[1-H\left(\varphi_{b x}\right)\right] \tilde{f}_{b}+\left[1-H\left(\varphi_{l x}\right)\right] f_{x}\right\}} .
\end{aligned}
$$

We put together the equations for the aggregate budget constraint (5.1), aggregate labor demand (5.2), aggregate labor supply (3.2), aggregate capital demand (5.3), aggregate capital supply (3.3), final output technology (4.1), domestic output technology (4.6), domestic and foreign demand for intermediate goods ( 4.2 ) and $(4.4)$ ), the equation that relates the bank rate to the bond rate (3.4), the definition of the domestic price level (4.7) and the aggregate price level (4.3), as well as the conditions that pin down the marginal productivity levels for the marginal producer (4.11), the marginal exporter 4.12), the marginal bond issuer (4.13), and the number of firms 5.6. Using the calibration that we discuss below, we solve for aggregate values (output $Y$, household consumption $C$ ) the level of financing (by bank borrowers, $K_{l d}+K_{l x}$ and by bond issuers $\left.K_{b d}+K_{b x}\right)$, sectoral output $\left(y_{d}\right.$ and $\left.y_{m}\right)$, the marginal productivity levels (for domestic producers, $\varphi_{l d}$, exporters, $\varphi_{l x}$, and bond issuers $\varphi_{b x}$ ), the number of firms $n$, and the relative prices (the domestic aggregate price level $P$, the domestic price level $p_{d}$, the wage rate $w$, and the two interest rates $r_{b}$ and $r_{l}$ ). For the numerical analysis we make the standard assumption that idiosyncratic productivity draws are Pareto distributed, so that $H(\varphi)=1-\varphi^{-\theta}$.

Conceptually, our model where firms pay a higher fixed cost to attain a lower marginal cost of financing draws on the mechanics in models of technology upgrading by Yeaple (2005) and Bustos (2009), where an endogenous number of firms has the option to pay a higher fixed cost to attain a lower marginal cost. Our model differs in our interpretation of the institutions driving the fixed and marginal cost differentials, but also in the fact that we fully endogenize the both the supply and 
prices of two factor inputs, labor and capital, so that the entire size and structure of the economy is endogenous. The disutility of labor in the utility function combines with decreasing marginal returns to labor and capital, as well as the bottom-heavy distribution of firm-specific efficiency levels, to allow us to do this. The mechanism allows recursive effects between the labor supply and the capital stock, as changes in the household labor supply affect household income and thus the amount of the final output they are willing to devote to savings (capital) versus consumption.

\subsection{Calibration}

We calibrate the model using a value for the elasticity of substitution between domestic varieties of intermediate goods, $\sigma=8$, coinciding with findings by Feenstra (1994), Broda and Weinstein (2006), and Eaton and Kortum (2002). The results are robust to higher and lower values, $4 \leq \sigma \leq 11$. We set $\theta$ equal to $\sigma$ so that the output-weighted distribution of efficiency parameters $(\theta-(\sigma-1))$ equals 1, a lower bound for the range found by Del Gatto, Ottaviano, and Pagnini (2008). The elasticity of substitution between domestic varieties and imported intermediate goods must be lower than $\sigma$ for the model to converge in the numeric simulations. We choose $\varepsilon=2$ as per Ruhl (2004) and Feenstra, Obstfeld, and Russ (2009). We choose a world export market, $Y^{*}$, that is approximately five times larger than the domestic market. The results are robust to larger values of $Y^{*}$. We choose this value because the parameter is not the principal focus of the model and assigning this magnitude allows us to vary the financial parameters of the model freely without violating the condition for the existence of bank-borrowing exporters, equation (4.14). Composite estimates of tariffs and transport costs are difficult to pin down, but Hummels 2007) describes levels of $\tau$ equal to approximately 1.06 for the United States and 1.22 for Latin America. We vary $\tau$ from 1.05 to 1.25 .

For the calibration of the financial friction parameters we follow Russ and Valderrama (2009) who discuss estimates of $f_{b}, f_{l}, \mu$, and $\delta$. We vary $f_{b}$ from a level twice as large as $f_{l}$, which corresponds to estimates for the United States, to a level about 10 times as large as $f_{l}$, a value corresponding roughly to Pakistan. Brazil, for instance, would have an intermediate value of bond issuance costs, approximately five times as large as $f_{l}$. The parameters $\mu$ and $\delta$ are more difficult to calibrate due to the variety of estimations available and the rather new stylized fact that both vary over the business cycle and are positively correlated (at least in the United States). The 
lowest value of "loss given default" in the finance literature, 0.08, is from Portugal for secured loans after 48 months of recovery effort, which is quite close to the lowest value recorded for the U.S. on structured loans, 0.13 . We choose 0.10 as our lower bound for $\mu$ in the experiments below. As our upper bound, we choose 0.3 , which is roughly equal to the average of 0.318 found for Latin America between 1970 and 1996. These figures also coincide with the range of monitoring costs cited by Carlstrom and Fuerst (2001), who use estimates of bankruptcy costs to calibrate this parameter. Estimates of the default rate $\delta$ vary widely, from less than 1 percent in South Korea to 6 percent in Portugal, to almost 12 percent for small businesses in the United States in 2008. We choose a middle ground of 5 percent, $\delta=0.05$.

\section{Bank and bond market frictions in the small open economy}

In this section, we show the results of the numerical analysis of the model. First, we analyze the impact that policies aimed at financial development have on intra-industry reallocation, export participation, real exchange rates, aggregate output, and welfare. Then, we study how the gains from trade liberalization depend on the level of financial development of a country. Finally, we study how changes in trade openness help determine the level of financial development in a country, even when the primitive financial parameters of the model (the fixed costs and the relative marginal costs of bank borrowing and bond issuance) do not change.

We first examine the intra-industry reallocation that underlies financial market development in a small open economy and its implications for trade and aggregate welfare. Figure 2 shows the level of firm output as a function of a firm's idiosyncratic productivity level $\varphi$ and how that level changes as a result of a drop in the fixed cost of bond issuance. As the cost of bond issuance falls, some firms switch from bank borrowing to bond issuing. The switchers are the most efficient firms that use bank financing before the reduction in issuance costs. It is striking here that output increases among these midsize firms, but falls for the largest and smallest firms, who are not switching their financing choice. This occurs as switchers begin to exploit their new lower cost of financing capital expenditures by charging lower prices, drawing domestic market share away from nonswitchers and expanding exports. Moreover, the figure also shows that while the productivity of the marginal bond issuer $\left(\varphi_{b x}\right)$ falls, the productivity levels for the marginal producer $\left(\varphi_{l d}\right)$ and the marginal 
exporter $\left(\varphi_{l x}\right)$ increase. So, while more firms are now bond issuers, those new entrants increase production. Moreover, the lowest productivity bank borrowers exit and the extensive margin of trade falls.

Table 1 indicates that aggregate output increases when bond fixed costs $f_{b}$ fall (either when bank monitoring costs $\mu$ are high or low), implying that the increase in production among switchers more than compensates for the reduction among nonswitchers. The capital stock increases, as well, meaning the size of total private credit increases. Bond issuance increases more than bank lending. But the reduction in the extensive margin of trade translates to a drop in the aggregate level of exports. The negative correlation between the ratio of bond issues to bank credit and aggregate exports conflicts with the positive correlation seen in Figure 1 . Thus, our model suggests that policies promoting bond market development do not fully explain actual bond market development as observed over the long run. We explain below why growth in trade is a more plausible driver of observed bond market development.

Now compare the results of a drop in the bond issuance cost $f_{b}$ with the results of a drop in the bank monitoring cost $\mu$. Figure 3 shows the level of firm output as a function of a firm's idiosyncratic productivity level. The drop in bank monitoring costs causes a reduction in the marginal costs of capital for bank borrowers. This allows all bank-borrowing producers to charge lower prices, capture a greater market share, and increase profits. As a result, some firms that previously issued bonds switch to borrowing from banks ( $\varphi_{b x}$ rises). Moreover, the lower marginal capital costs apply to all bank borrowers, both previous exporters and nonexporters. Thus, there is entry into exporting ( $\varphi_{l x}$ drops) and into production ( $\varphi_{l d}$ drops). As the last column of Table 1 shows, a drop in bank monitoring costs leads to an increase in aggregate output, which increases labor demand and real wages, increasing marginal costs for all firms. As the figure shows, output is reallocated toward relatively less efficient firms who charge relatively higher prices both because of their inferior efficiency and because all bank borrowers still pay higher marginal costs for credit than bond issuers).

The critical point is that the switchers are also exporters. It is here that the theory of firm size and bond market development intersects with modern trade theory. When firms switch from bank loans to bond issues as the issuance cost $f_{b}$ decreases, or reap the benefits of lower interest rates as monitoring costs $(\mu)$ fall, the reduced cost of financing capital expenditures directly results 
in lower marginal costs of production. The drop in marginal costs affects both the intensive and extensive margin of exports. What is more, the two policies each impact the extensive margin and the aggregate level of exports differently.

Figure 4 depicts the extensive margin of trade $\left(n_{l x}+n_{b x}\right)$ as trade costs vary for given levels of the parameters that determine bond and bank frictions and the trade costs. The top three lines graph the extensive margin of trade when export entry is "cheap" $\left(f_{x}=f_{l}\right)$. The bottom three lines graph the extensive margin of trade when export entry is "expensive" $\left(f_{x}=10 \times f_{l}\right)$. The solid black lines graph the extensive margin of trade when financial frictions are "high" $\left(f_{b}=5, \mu=0.3\right)$. The dotted lines show how the extensive margin of trade changes when bond issuance costs fall $\left(f_{b}=5\right)$. The dashed lines show how the extensive margin of trade changes when bank monitoring costs fall $(\mu=0.1)$.

Figure 4 reveals that increased bank efficiency (a drop in $\mu$ ) has a big positive impact on the extensive margin of trade and, as we see in Table 1, increases aggregate exports. Smaller monitoring costs allow many more firms to export because the high marginal cost of capital financed through bank borrowing is the principal obstacle for the marginal exporter when $f_{x}$ is low. Smaller monitoring costs also allow incumbent bank borrowers to slash their prices, increasing market demand for their exports. Conversely, reducing the fixed cost of bond issuance $f_{b}$ shrinks the extensive margin and aggregate exports. The switching into bond issuance by medium-sized firms pulls market share away from the less-efficient smaller firms who must stick with financing through bank loans with higher interest rates. Competing with the suddenly even lower prices of their more efficient rivals who switch to bond issues forces the least productive exporters, who remain dependent on expensive bank credit, to quit exporting. The effects on the extensive margin of trade are much smaller but work in the same direction if a large fixed cost of exporting dampens firms' ability to switch into exporting when their marginal costs of financing fall.

The increase in output under both sets of experiments translates into rising consumption, yielding the outcome seen in Figure 5b; lowering bond issuance costs and lowering bank monitoring costs result in rising welfare. When the banking sector is less efficient ( $\mu$ is high) switching has a bigger effect on firms' marginal costs and their output prices. This means the switching also pushes down the aggregate price level and boosts the real wage more than when the monitoring costs are low. Table 1 shows that the real wage increases twice as much in response to a drop in $f_{b}$ when $\mu$ is high 
compared to when $\mu$ is low. As a result, we see in Figure 5b that reducing bond market frictions gives the biggest boost to welfare when monitoring costs or other similar frictions in the banking sector are high.

\subsection{Financial choice and the gains from trade openness}

As discussed above, a number of studies have brought to light the influence that financial frictions have on gains from trade through comparative advantage. Here, all gains from trade occur through intra-industry reallocation and financial switching. Not surprisingly, gains from trade can vary to the degree that export volume increases given various levels of financial transaction costs. Under our balanced trade condition, greater aggregate export volume allows the small country's firm managers to purchase more standardized bundles of an imported intermediate good and is correlated with increases in aggreage output. However, there is a second channel for gains from trade to emerge through financial switching. Trade liberalization increases the size of the export market, allowing the biggest bank-dependent exporters to tackle the large issuance cost with the extra export revenues and begin to issue bonds. Firms switching to bond issuance have lower marginal costs and therefore cut prices, boosting output, the real wage, and welfare. The financial switching channel is strongest when issuance costs are low.

Figure 6 depicts the level of the small open economy's steady-state read GDP $(Y)$ as a function of iceberg trade $\operatorname{costs} \tau$ for given levels of the parameters that determine bond and bank frictions and fixed trade costs. The solid black line graphs welfare for each level of $\tau$ when financial frictions are "high" $\left(f_{b}=5, \mu=0.3\right)$. The dotted line shows how welfare changes when bond issuance costs fall $\left(f_{b}=1\right)$. The dashed line shows how welfare changes when bank monitoring costs fall $(\mu=0.1)$. Aggregate output clearly increases when trade costs fall, regardless of the level of financial transaction costs. Likewise, aggregate output increases when either type of financial transaction cost falls, regardless of the degree of trade liberalization. However, the gains from trade in terms of output growth per incremental drop in $\tau$ - reflected in the slopes of the linesare slightly larger when the issuance cost falls, as opposed to when monitoring costs fall. This is not to say that one policy is optimal, only to illustrate that targeted financial policies affect gains from trade liberalization differently. Because lowering the issuance cost by itself reduces aggregate exports, it is clear that the increased gains from trade that materialize when issuance costs are low 
stem from the financial switching channel, not from trade volume. Gains from trade actually fall slightly when bank monitoring costs are low because low interest rates on bank loans strengthen the spillover effect from increased imports, which pulls new firms into active production from the bottom end of the efficiency spectrum. The amplified reallocation of domestic production toward the lower end of the efficiency spectrum for each incremental reduction in $\tau$ dampens the gains from trade compared to when monitoring costs are high.

Increasing the fixed trade cost $f_{x}$ (not shown here) lowers output for any given level of iceberg costs regardless of the level of financial transaction costs. Increasing $f_{x}$ does not alter the order or slopes seen in Figure 6. Nonetheless, a high fixed cost of exporting dampens the ability of bank borrowers who serve only the domestic market to switch into exporting. Thus, it reduces the output and welfare gains attained when reducing bank monitoring costs relative to those attained when reducing bond issuance costs. ${ }^{18}$

\subsection{Intra-industry reallocation and the real exchange rate}

Reducing bond issuance costs and lowering bank monitoring costs have opposite effects on the real exchange rate. The exit of the least productive firms from the domestic market when $f_{b}$ falls, as described in the previous section, combines with the price reductions by firms switching from banks to bonds and pushes down the aggregate price level. The real exchange rate depreciates as domestic goods become cheaper relative to foreign goods.

Figure 7 depicts the log level of the real exchange rate as a function of the bond issuance cost $f_{b}$ for two different levels of bank monitoring costs, "high" $(\mu=0.3)$ and "low" $(\mu=0.1)$. An increase in the real exchange rate represents a real exchange rate depreciation. Figure 7 shows that the real exchange rate depreciates as the bond issuance cost drops. It also demonstrates that regardless of the level of transaction costs in the bond market, reducing the bank monitoring cost causes a real exchange rate appreciation. This occurs for two reasons. First, cheaper interest rates on bank loans allow new, small firms to enter the market. Each additional new firm is less efficient than

\footnotetext{
${ }^{18}$ The influence of the size of $f_{x}$ on welfare is not linear beyond the point when it is large enough to push bank borrowers out of the export market. When it is outlandishly large $\left(f_{x}=175,17\right.$ times the size of the cost of bond issuance), only a very small fraction of bond issuers (no bank borrowers) are exporters. As in the previous cases, lowering banks' monitoring costs still increases welfare, but lowering the cost of bond issuance increases the extensive margin of trade and, by pulling resources away from production for domestic consumption, actually has almost zero welfare effect.
} 
the last and absorbs market share from more efficient incumbents because final goods producers are willing to pay somewhat higher prices to add extra varieties to their assembly process. The second reason is that, when banks become more efficient, marginal bond issuers switch to bank loans as their choice for external financing. Since bank loans carry higher marginal costs because of the assumption of constant CES markups, this means the switchers charge higher prices. The last three columns in Table 1 demonstrate that the aggregate price level drops when issuance costs fall, but actually rises a bit when monitoring costs fall, which moves the exchange rate in opposite directions.

\subsection{The impact of trade policy on financial development and the real exchange rate}

Trade policy by itself can influence firms' choice of financial instrument, influencing aggregate measures of financial development. Figure 8 depicts the level of a firm's output as a function of the idiosyncratic productivity parameter $\varphi$ for two different levels of trade costs, "high" $(\tau=1.25)$ and "low" $(\tau=1.05)$. In Figure 8 , we see that both bond issuance and bank borrowing increase along the extensive margin and drop on the intensive margin among exporters when trade costs fall. Falling trade costs allow exporters to expand in number, but with decreased output per firm as expansion by new exporters pushes up the real wage.

Table 2 shows that the net effect of a reduction of the iceberg trade cost $\tau$ on both types of credit is positive - both bond issuance and bank borrowing increase as an economy becomes more open to trade. The amount of bank loans increases among nonexporters as the complementarity effect from export growth boosts demand for domestic varieties and allows more small firms (all bank borrowers) to start producing. Some domestic bank borrowers also switch to exporting, further increasing the demand for bank credit. This entry outweighs the drop in the per-firm demand for bank loans among incumbent bank-borrowing exporters and nonexporters, who reduce their output a bit due to the new competition for domestic market share and the increasing real wages. Nonetheless, it is overshadowed by the net increase in bond issues, as the reduction in trade cost allows the largest exporting bank borrowers to switch to bond issues. The increase in demand for bond issues relative to bank credit as trade costs fall holds regardless of the level of financial development in our experiments. 
This type of trade liberalization improves common measures of financial market development. Figure 9 depicts three common measures of financial market development, the stock of credit as a ratio of GDP and the stock of bond issues as a ratio of the stock of total private credit, and the stock of bond issues relative to bank credit. All rise as iceberg trade costs fall, simply because decreasing the iceberg trade cost expands the extensive and intensive margin of trade and because the resulting boost in imported intermediate goods stimulates additional demand for domestic intermediate varieties, prompting the entry of new nonexporting suppliers. Increased export revenues allow the very largest bank borrowers to cover the large bond issuance cost and begin issuing bonds, increasing the total level of bond issues despite the reallocation of production away from incumbent issuers. The increased demand for domestic varieties to complement the jump in imports (brought about through the balanced trade condition when exports increase) draws new domestic producers into the market. Their demand for bank loans, as well as increased demand for loans by a fraction of bank borrowers who expand into exporting, also boost the level of total bank credit. Because the firms switching into bond issuance are much larger than the new and expanding bank borrowers, bond issuance rises relative to bank borrowing, as well as as a share of total private credit and as a share of GDP: the relative size of the bond market increases along with exports. Our purpose is to provide a unified analytical framework to address such patterns, not to test them with formal empirical analyses. However, the positive relationship between the ratio of bond issues to bank credit and export growth seen in Figure 1 suggests that within the context of our model, growth in trade is driving growth in the relative size of bond markets over the long term, rather than reductions in bond market transactions costs.

The last column of Table 2 shows that the type of trade openness a country pursues also has an effect on its pattern of financial development. Earlier, we noted that a low fixed cost of exporting allows more switching into exporting by bank borrowers when bank monitoring costs fall. In the last column of Table 2, we again see this sensitivity of bank borrowers to the size of the fixed export cost. If trade liberalization focuses on fixed barriers to export participation, rather than ad valorem tariffs and transport costs, the growth of bank borrowers who suddenly begin exporting (evident in the rising value of $n_{l x}$ and falling value of $\left.\varphi_{l x}\right)$ increases the aggregate level of bank credit relative to bond issuance. In fact, the rising real wage makes some bond issuers unable to cover the large fixed cost of issuance, forcing them to switch to bank borrowing, indicated by the drop in $n_{b x}$ and 
the rise in $\varphi_{b x}$. This switching results in a drop in aggregate exports.

When iceberg trade costs fall, the expanded production of the largest bank borrowers switching into bond issuance is directed in large part toward the export market. The entry of small, less efficient domestic producers therefore can push up the domestic price level and causes a real exchange rate appreciation. The appreciation is greatest when bank monitoring costs are low, which allows for more entry by the small new high-cost domestic producers. It is weakest when the fixed cost of bond issuance costs are small, so that more bank-borrowing exporters switch to the low-yield bond issues and their decreased marginal costs (and prices) dampen the effect of new entry by small firms on the aggregate domestic price level.

\section{Conclusions}

In this paper, we have introduced the concept of financial choice into a modern model of trade in a small open economy. While previous trade literature has examined the impact of singular financial frictions, we depart from this simplifying assumption and examine the effect of financial choice- the existence of more than one source of financing for capital investment, where each source carries different levels of transaction costs. We calibrate transaction costs for bank loans characterized by higher interest rates and lower fixed costs than for bond issues, in accordance with stylized facts from studies of financial markets.

Using comparative statics, we find that although both policies increase domestic output, consumption, and welfare, subsidizing bank credit or improving efficiency in the banking sector has a very different effect on the extensive margin of trade and the real exchange rate in comparison with policies that increase access to the bond market by reducing the fixed cost of bond issuance. Policies favoring bank credit cause a reallocation of output and profit toward firms with higher marginal costs, as they induce some potential bond issuers to switch to using bank loans and allow new firms to enter at the bottom end of the efficiency continuum. The result is an appreciation of the real exchange rate but also an increase in the extensive margin of trade and aggregate exports, as some incumbent bank borrowers find that lower interest rates allow them to start exporting profitably or to expand their volume of exports.

In contrast, increasing access to the bond market (lowering the fixed cost of issuance) causes 
mid- to large-sized firms to switch from bank loans with high interest rates to low-yield bonds. The reduced cost of capital allows switchers to charge lower prices, boosting their market share in the domestic and world markets. The result is a real exchange rate depreciation. Reducing bond issuance costs generates a very small negative impact on the extensive margin of trade as nonswitchers (incumbent bank borrowers who continue using bank loans) grapple with higher real wages and reduced domestic market share owing to increased competition from switchers, though aggregate exports rise because of an increase in the intensive margin. Gains from trade liberalization are amplified when the fixed costs of bond issuance are low through a financial switching channel: scale effects from widening export markets help more firms begin to issue bonds, lowering their marginal costs and the aggregate price level.

We also demonstrate that trade liberalization by itself can drive measures of financial development. By increasing exports among the mid-size bank borrowers and all (large) bond issuers, a drop in iceberg trade costs increases the aggregate level of bond issues relative to bank credit, as well as the overall volume of exports. Though we do not test the model empirically, the positive correlation between aggregate exports and the ratio of total bond issuance to bank credit is consistent with observed patterns of exports and financial development at long horizons. We also show that gains from incremental reductions in iceberg trade costs are somewhat larger when the fixed costs of bond issuance are low due to a financial switching channel, but that low bank monitoring costs dampen gains from trade liberalization by amplifying a trade spillover effect that pulls less efficient new firms into active production.

The analysis leaves a number of open questions. We have not considered participation by foreign banks or financial institutions, which obviously are influential players in the domestic financial markets of small open economies. Consideration of financial choice in large open economies could reveal insights into the transmission of business cycles across countries. In particular, bank monitoring costs and the default rate vary over the business cycle, which may affect capital flows and current account adjustment in response to various domestic and foreign macroeconomic shocks. Finally and perhaps most importantly, the banking sector in this model is perfectly competitive, leaving any interactions between bond market development and the market power of banks unexplored. These complexities leave interesting paths for future research, but do not detract from our central finding that firms' choices between different financial instruments and their export decisions interact with 
nontrivial implications for the intensive and extensive margins of trade, the real exchange rate, and welfare. 


\section{References}

Antràs, P., and R. Caballero (2009): "Trade and Capital Flows: A Financial Frictions Perspective," Journal of Political Economy, 117(4), 701-744.

Baliga, S., And B. Polak (2004): "The Emergence and Persistence of the Anglo-Saxon and German Financial Systems," The Review of Financial Studies, 17(1), 129-163.

Bardhan, P., And K. Kletzer (1987): "Credit Markets and Patterns of International Trade," Journal of Development Economics, 27(1), 57-70.

Broda, C., And D. E. Weinstein (2006): "Globalization and the Gains from Variety," The Quarterly Journal of Economics, 121(2), 541-585.

Burger, J. D., And F. E. Warnock (2006): "Local Currency Bond Markets," IMF Staff papers, 53(Special Issue), 133-146.

Bustos, P. (2009): "Trade Liberalization, Exports and Technology Upgrading: Evidence on the impact of MERCOSUR on Argentinean Firms," Forthcoming, American Economic Review.

Carlstrom, C. T., and T. S. Fuerst (1997): "Agency Costs, Net Worth, and Business Fluctuations: A Computable General Equilibrium Analysis," The American Economic Review, 87(5), 893-910.

(2001): "Monetary shocks, agency costs, and business cycles," Carnegie-Rochester Conference Series on Public Policy, 54(1), $1-27$.

Chaney, T. (2005): "Liquidity Constrained Exporters," Working paper, University of Chicago.

De Fiore, F., and H. Uhlig (2005): "Bank Finance versus Bond Finance: What Explains the Differences between US and Europe?," Working Paper 547, European Central Bank.

Del Gatto, M., I. G. Ottaviano, and M. Pagnini (2008): "Openness to Trade and Industry Cost Dispersion: Evidence from a Panel of Italian Firms," Journal of Regional Sciences, 48(1), $97-129$. 
Diamond, D. W. (1991): "Monitoring and Reputation: The Choice between Bank Loans and Directly Placed Debt," Journal of Political Economy, 99(4), 689-721.

Do, Q.-T., And A. A. Levchenko (2007): "Comparative Advantage, Demand for External Finance, and Financial Development," Journal of Development Economics, 86(3), 796-834.

Dunne, T., M. J. Roberts, and L. Samuelson (1988): "Patterns of Firm Entry and Exit in U.S. Manufacturing Industries," The RAND Journal of Economics, 19(4), 495-515.

Eaton, J., And S. Kortum (2002): "Technology, Geography, and Trade," Econometrica, 70(5), $1741-1779$.

Endo, T. (2008): "Broadening the offering choice of corporate bonds in emerging markets: Costeffective access to debt capital," Policy Research Working Paper 4655, The World Bank.

Feenstra, R. C. (1994): "New Product Varieties and the Measurement of International Prices," The American Economic Review, 84(1), 157-177.

Feenstra, R. C., M. Obstfeld, and K. N. Russ (2009): "In Search of the Armington Elasticity," Unpublished manuscript, University of California, Davis.

Fillat, J. L., And S. Garreto (2009): "Risk, Returns, and Multinational Production," Manuscript, Boston University.

FreiXas, X., And J.-C. Rochet (1997): Microeconomics of Banking. MIT Press.

Ghironi, F., And M. J. Melitz (2005): "International Trade and Macroeconomic Dynamics with Heterogeneous Firms," The Quarterly Journal of Economics, 120, 381-411.

Greenspan, A. (1999): "Lessons from the Global Crises'," remarks before the World Bank Group and the International Monetary Fund, Program of Seminars, Washington, D.C.

Hong Kong Monetary Authority (2001): "Cost-Benefit Analysis of Developing Bond Markets," in Quarterly Bulletin, vol. 29.

Hummels, D. (2007): "Transportation Costs and International Trade in the Second Era of Globalization," Journal of Economic Perspectives, 21(3), 131-154. 
Levchenko, A. A., R. Rancière, and M. Thoenig (2009): "Growth and Risk at the Industry Level: The Real Effects of Financial Liberalization," Journal of Development Economics, 89, $210-222$.

Manova, K. (2008): "Credit constraints, equity market liberalizations and international trade," Journal of International Economics, 76(1), 33-47.

Melitz, M. J. (2003): "The Impact of Trade on Intra-Industry Reallocations and Aggregate Industry Productivity," Econometrica, 71(6), 1695-1725.

Mundell, R. A. (1957): "International Trade and Factor Mobility," The American Economic Review, 47, 321-55.

Razin, A., And E. Sadka (2007): Foreign Direct Investment: Analysis of Aggregate Flows. Princeton University Press, Princeton, NJ.

RuhL, K. J. (2004): “The International Elasticity Puzzle," Discussion paper, NYU Stern School of Business.

Russ, K. N. (2009): “The New Theory of Foreign Direct Investment: Merging Trade and Capital Flows," International Finance, 12(1), 107-119.

Russ, K. N., And D. Valderrama (2009): "A Theory of Banks, Bonds, and the Distribution of Firm Size," Working Paper 15454, National Bureau of Economic Research.

Smith, K. A., And D. Valderrama (2009): "The composition of capital inflows when emerging market firms face financing constraints," Journal of Development Economics, 89(2), 223-234.

World Bank, and International Monetary Fund (2001): Developing Government Bond Markets : A Handbook. World Bank : International Monetary Fund, Washington, D.C.

Yeaple, S. (2005): "A Simple Model of Firm Heterogeneity, Trade, and Wages," Journal of International Economics, 65(1), 1-20. 


\section{A Derivation of bank interest rate and bond yield}

We assume that firms must borrow to finance their capital expenditures. In addition, intermediaries also front the fixed financing fees, which are paid with interest after firms collect their sales revenues. ${ }^{19}$ An intermediary's participation constraint implies that the expected cost of monitoring nonperforming loans or defaulted bonds is equal to the expected gains from making loans to successful firms who repay loans or bond issues with no monitoring (no default),

$$
\delta n_{j} \mu_{j} P\left(\bar{K}+f_{j}\right)=(1-\delta) n_{j}\left(r_{j}-r\right) P\left(\bar{K}+f_{j}\right), \quad j \in\{l, b\}
$$

where $P\left(\bar{K}+f_{j}\right)$ is the average loan size, $\mu_{j}$ is the monitoring cost, and $r_{j}-r$ is the net return on earned interest revenues after paying interest on bank deposits or to bond purchasers (the intermediaries earn the spread as part of the underwriting process). Note that default means (1) the intermediary incurs monitoring cost $\mu_{j}$ and receives no interest on loans.

Solving for $r_{j}$, we obtain the interest rate on loans or bond issues as a function of the risk-free interest rate from the consumer's problem:

$$
r_{j}=r+\frac{\delta \mu_{j}}{1-\delta}
$$

We assume that the monitoring costs for bond investors is less than the monitoring cost for bank loans, corresponding with the financial literature on monitored versus unmonitored lending. If $\mu_{l}$ is greater than $\mu_{b}$, then $r_{l}>r_{b}$. For simplicity and without loss of generality, we assume that $\mu_{b}$ equals zero, so that

$$
r=r_{b}=r+\frac{\delta \mu_{b}}{1-\delta}
$$

\section{B All bond holders export when some bank borrowers export}

We assert that if some bank borrowers export, then all bond issuers export and offer a proof by contradiction:

\footnotetext{
${ }^{19}$ This assumption simplifies the solution for the interest rate spread, but is not necessary for the results of the model.
} 
Proof. Suppose that at least one bank borrower exports and at least one bond issuer does not export, so that there exists some $\varphi_{b}<\varphi_{b x}$. Given the condition in equation (4.10) holds, then we have one of two cases - either there exists a set of thresholds $\varphi_{l}, \varphi_{b}, \varphi_{l x}, \varphi_{b x}$ such that either:

$$
\begin{cases}\varphi_{l}<\varphi_{b}<\varphi_{l x}<\varphi_{b x} ; & (\text { Case I) } \\ \varphi_{l}<\varphi_{b}<\varphi_{b x}<\varphi_{l x}, & \text { (Case II) }\end{cases}
$$

holds.

In Case I, the marginal bond issuer serving only the domestic market must be indifferent between using bank and bond financing $\left(\pi_{b d}\left(\varphi_{b}\right)=\pi_{l d}\left(\varphi_{b}\right)\right)$ and the marginal exporting bond issuer must also be indifferent between bank and bond financing $\left(\pi_{b}^{T}\left(\varphi_{b x}\right)=\pi_{l}^{T}\left(\varphi_{b x}\right)\right)$.

Substitution in the relevant profit functions, the first condition yields

$$
\begin{aligned}
\pi_{b d}\left(\varphi_{b}\right) & \equiv \pi_{l d}\left(\varphi_{b}\right) \\
p_{b}\left(\varphi_{b}\right)^{1-\sigma} p_{d}^{\sigma-\epsilon} P^{\epsilon} Y-P f_{b} & =p_{l}\left(\varphi_{b}\right)^{1-\sigma} p_{d}^{\sigma-\epsilon} P^{\epsilon} Y-P f_{l} \\
p_{b}\left(\varphi_{b}\right)^{1-\sigma}-p_{l}\left(\varphi_{l}\right)^{1-\sigma} & =\frac{P\left(f_{b}-f_{l}\right)}{p_{d}^{\sigma-\epsilon} P^{\epsilon} Y} \\
\varphi_{b}^{\sigma-1} & =\frac{P\left(f_{b}-f_{l}\right)}{p_{d}^{\sigma-\epsilon} P^{\epsilon} Y}\left(\frac{w^{\alpha}}{\alpha^{\alpha}(1-\alpha)^{(1-\alpha)}}\right)^{\sigma-1}\left(r_{b}^{(1-\sigma)(1-\alpha)}-r_{l}^{(1-\sigma)(1-\alpha)}\right)^{-1} .
\end{aligned}
$$

Again substituting in the relevant profit functions, the second condition yields

$$
\varphi_{b x}^{\sigma-1}=\frac{P\left(f_{b}-f_{l}\right)}{p_{d}^{\sigma-\epsilon} P^{\epsilon} Y+\tau^{-\sigma} Y^{*}}\left(\frac{\alpha^{\alpha}(1-\alpha)^{(1-\alpha)}}{w^{\alpha}}\right)^{\sigma-1}\left(r_{b}^{(1-\sigma)(1-\alpha)}-r_{l}^{(1-\sigma)(1-\alpha)}\right)^{-1}
$$

However, because $\tau^{-\sigma} Y^{*}>0$, the right-hand side of equation (B.1) is strictly greater than the right-hand side of $(\bar{B} .2)$. This violates the condition that $\varphi_{b x}$ must be greater than $\varphi_{b}$ if some bond issuers do not export. Thus, these two conditions cannot both be true.

For Case II to be possible, the marginal exporting bank borrower must be indifferent between bank and bond finance $\left(\pi_{b}^{T}\left(\varphi_{l x}\right)=\pi_{l}^{T}\left(\varphi_{l x}\right)\right)$ and the marginal exporting bond issuer must prefer bond to bank financing $\left(\pi_{b}^{T}\left(\varphi_{b x}\right)>\pi_{l}^{T}\left(\varphi_{b x}\right)\right)$. 
The first condition yields

$$
\varphi_{l x}^{\sigma-1}=\frac{P\left(f_{b}-f_{l}\right)}{p_{d}^{\sigma-\epsilon} P^{\epsilon} Y}\left(\frac{w^{\alpha}}{\alpha^{\alpha}(1-\alpha)^{(1-\alpha)}}\right)^{\sigma-1}\left(r_{b}^{(1-\sigma)(1-\alpha)}-r_{l}^{(1-\sigma)(1-\alpha)}\right)^{-1}\left[1+\frac{\tau^{-\sigma} Y^{*}}{p_{d}^{\sigma-\epsilon} P^{\epsilon} Y}\right]^{-1}
$$

The second condition yields

$$
\varphi_{b x}^{\sigma-1}>\frac{P\left(f_{b}-f_{l}\right)}{p_{d}^{\sigma-\epsilon} P^{\epsilon} Y}\left(\frac{w^{\alpha}}{\alpha^{\alpha}(1-\alpha)^{(1-\alpha)}}\right)^{\sigma-1}\left(r_{b}^{(1-\sigma)(1-\alpha)}-r_{l}^{(1-\sigma)(1-\alpha)}\right)^{-1}\left[1+\frac{\tau^{-\sigma} Y^{*}}{p_{d}^{\sigma-\epsilon} P^{\epsilon} Y}\right]^{-1}
$$

Together, equations $(\overline{B .3})$ and $(\mathrm{B} .4)$ require that $\varphi_{b x}$ be greater than $\varphi_{l x}$, so it cannot be true that $\varphi_{l}<\varphi_{b}<\varphi_{b x}<\varphi_{l x}$

\section{Aggregation}

We simplify the expression for profits from domestic sales by a bank borrower:

$$
\begin{aligned}
\pi_{l d}(\varphi) & =\frac{1}{\sigma} p_{l}(\varphi) y_{l d}(\varphi)-P \tilde{f}_{l} \\
& =\frac{1}{\sigma}\left(\frac{p_{l}(\varphi)}{P}\right)^{1-\sigma} P Y-P \tilde{f}_{l} \\
& =\frac{1}{\sigma} P^{\sigma} Y p_{l}(\varphi)^{1-\sigma}-P \tilde{f}_{l} .
\end{aligned}
$$

Then total profits from domestic sales by all bank borrowers is:

$$
\begin{aligned}
\Pi_{l d} & =\frac{1}{\sigma} P^{\sigma} Y \frac{1}{H\left(\varphi_{b d}\right)-H\left(\varphi_{b d}\right)} \int_{0}^{n_{l} d} \int_{\varphi_{l d}}^{\varphi_{b d}} p_{l}(\varphi)^{1-\sigma} d H(\varphi) d i-n_{l d} \tilde{f}_{l} \\
& =\frac{1}{\sigma} P^{\sigma} Y n_{l d} p_{l}\left(\overline{\varphi_{l d}}\right)^{1-\sigma}-n_{l d} \tilde{f}_{l} \\
& =n_{l d} \pi_{l d}\left(\overline{\varphi_{l d}}\right) .
\end{aligned}
$$

We can similarly derive $\Pi_{l x}, \Pi_{b d}$, and $\Pi_{b x}$, so that aggregate profits (before discounting for the threat of exit shocks and fluctuations in marginal utility, etc.) equals

$$
\Pi^{T}=n_{l d} \pi_{l d}\left(\overline{\varphi_{l d}}\right)+n_{l x} \pi_{l x}\left(\overline{\varphi_{l x}}\right)+n_{b x} \pi_{b d}\left(\overline{\varphi_{b d}}\right)+n_{b x} \pi_{b x}\left(\overline{\varphi_{b x}}\right) .
$$


Then

$$
\bar{\pi}^{T}=\frac{\Pi^{T}}{n} .
$$

We derive the aggregate supply of labor and capital in the same way as aggregate profit, using the set of equations in 4.5). 


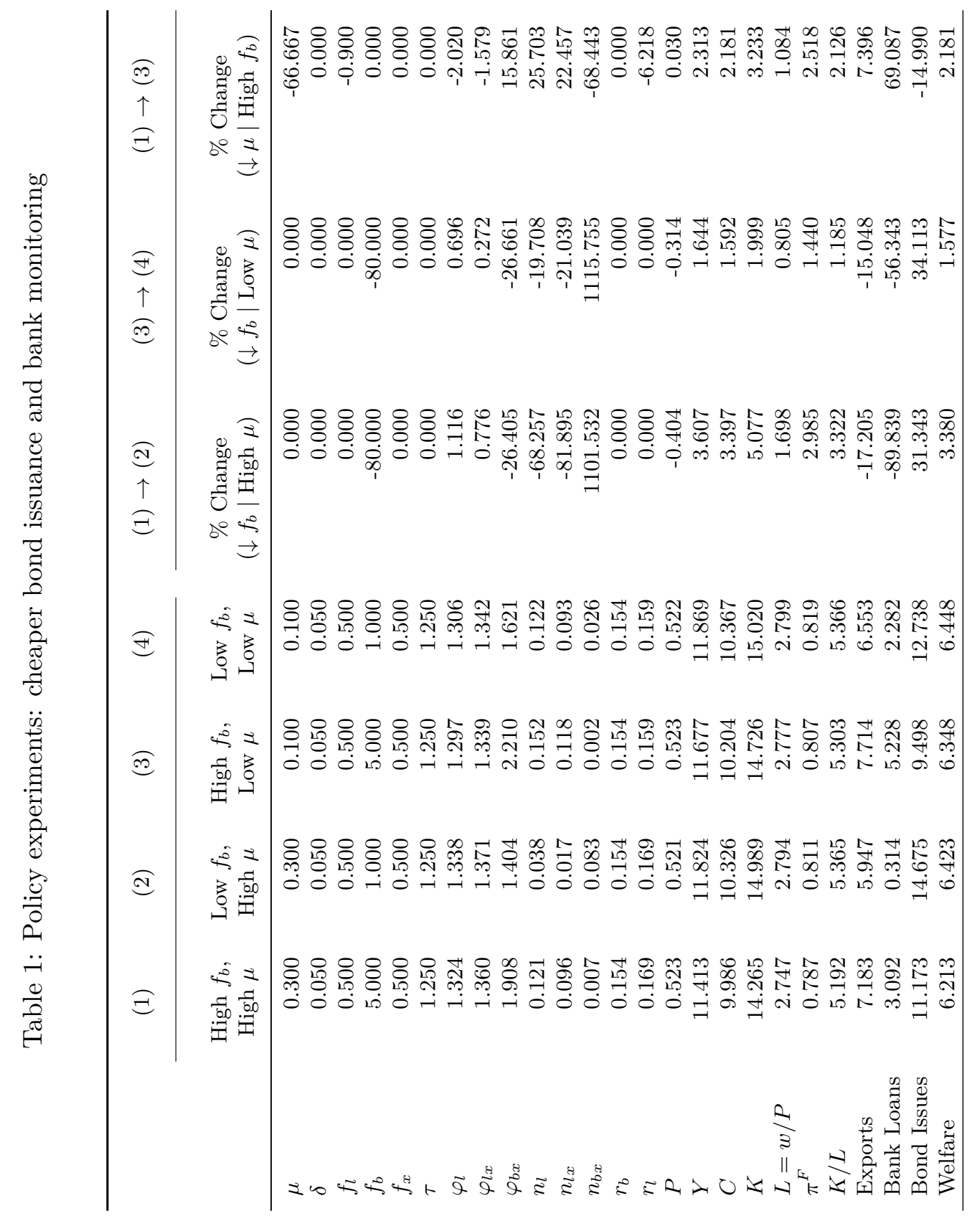




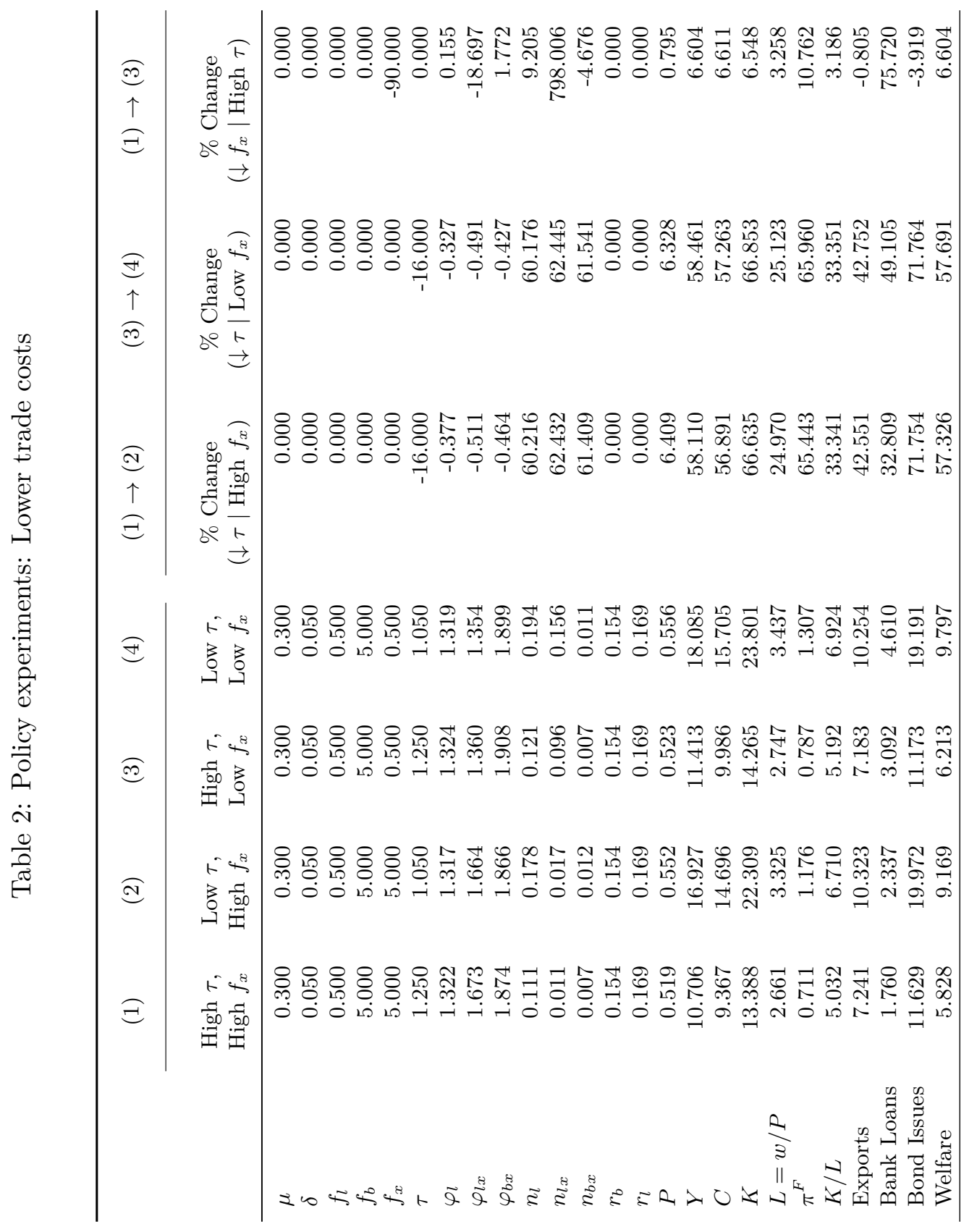




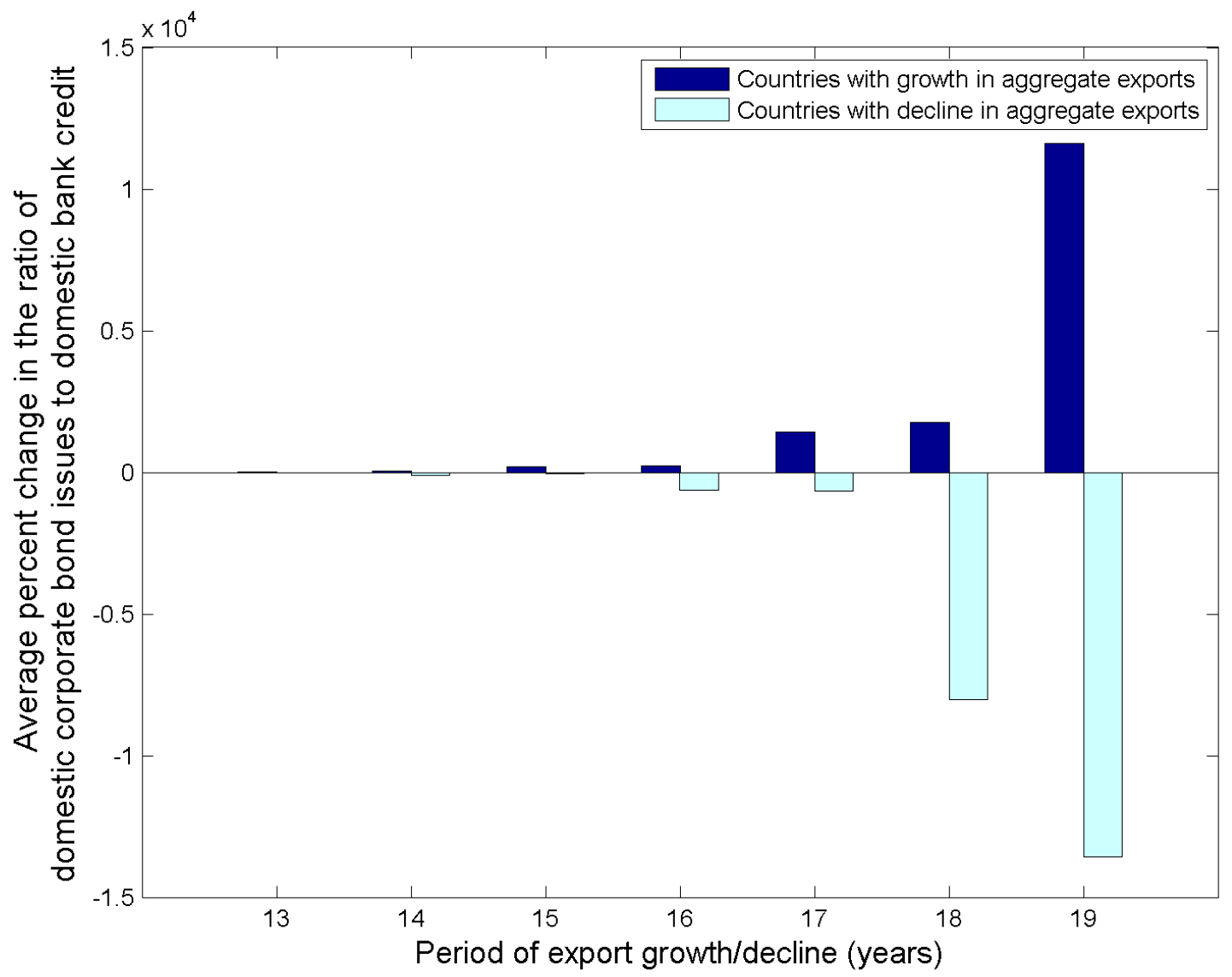

Figure 1: Export growth is associated with an increase in the level of domestic corporate bond issues relative to bank credit 


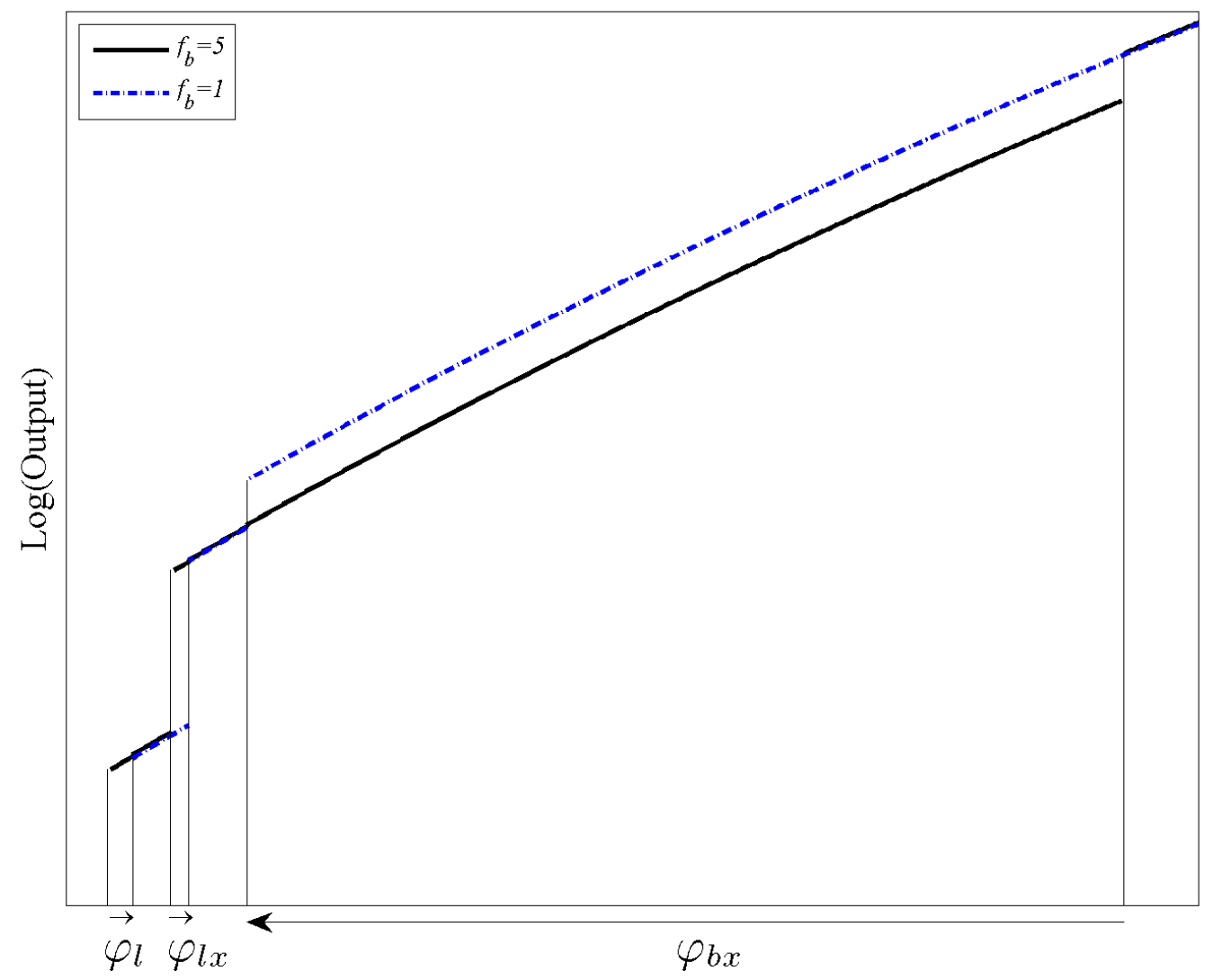

Figure 2: Reallocation of output across firm efficiency levels as bond fixed costs fall 


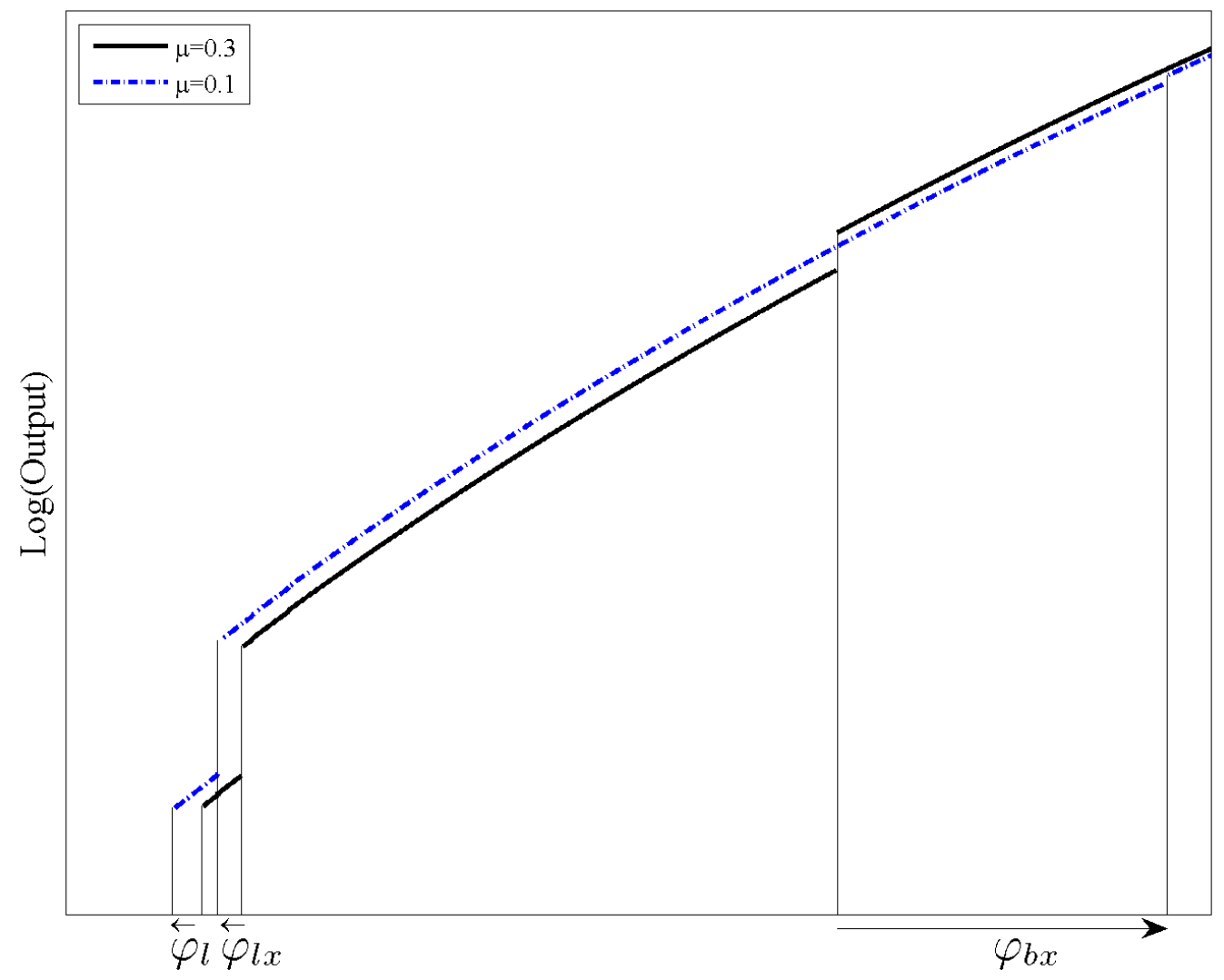

Figure 3: Reallocation of output across firm efficiency levels as bank monitoring costs fall 


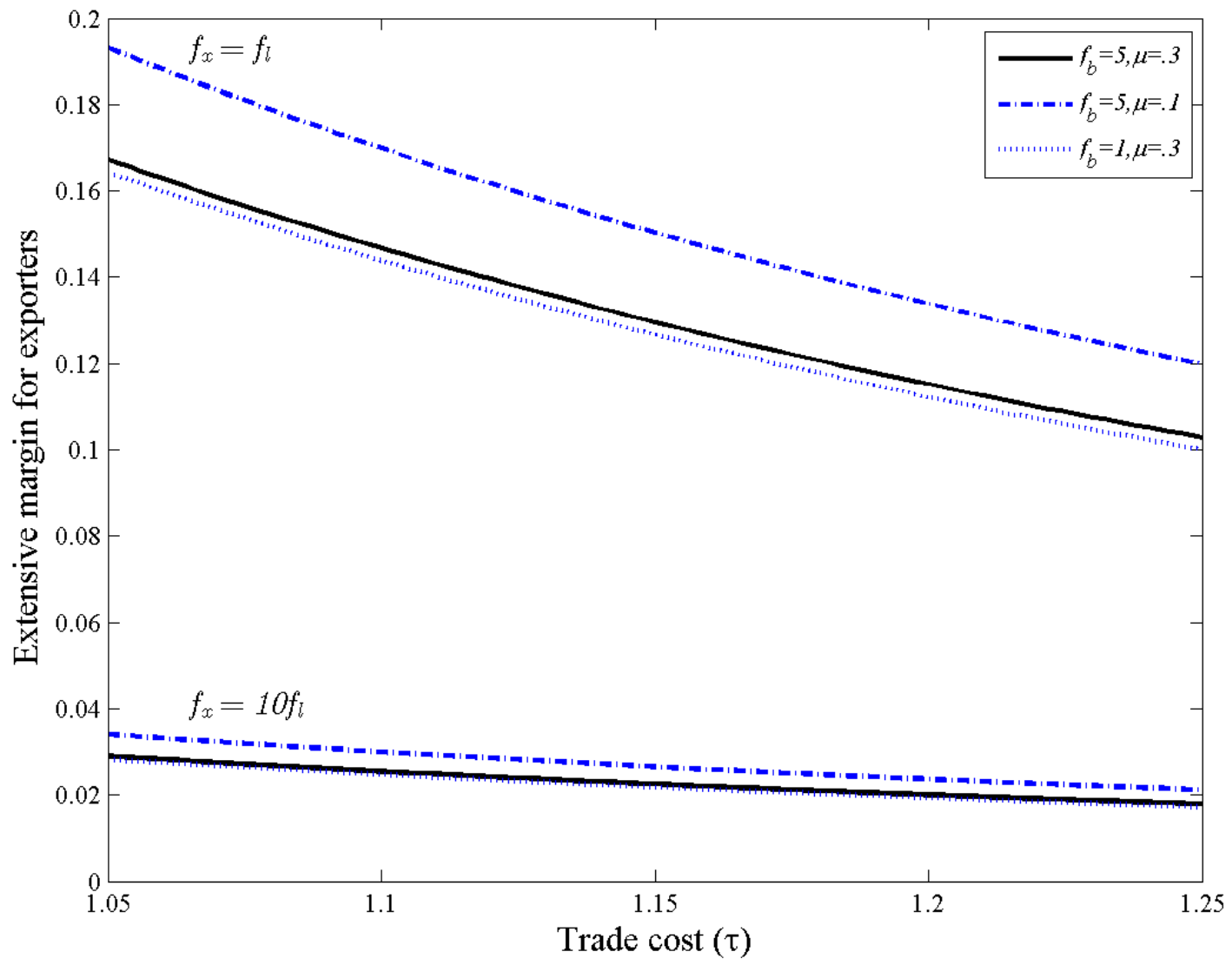

Figure 4: Reducing the bond issuance cost and the monitoring cost have opposite effects on extensive margin of trade 


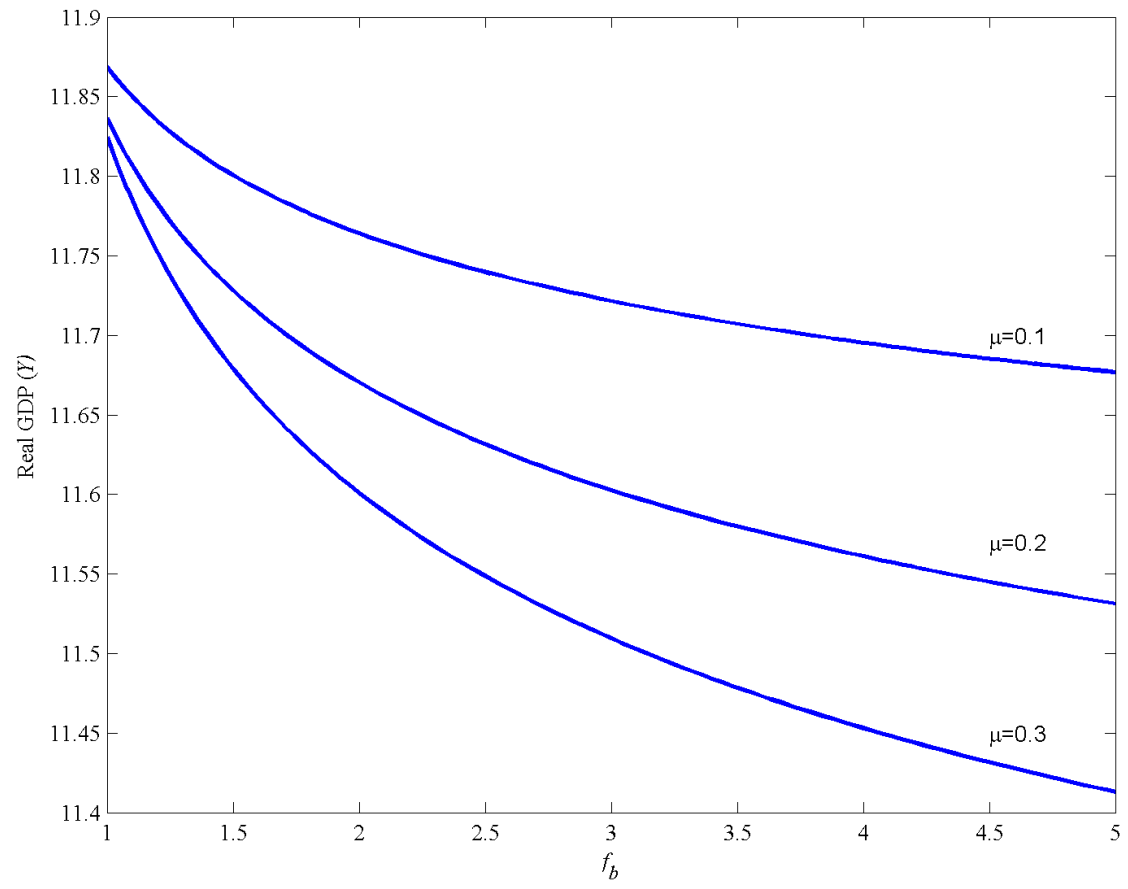

(a) Issuance costs, monitoring costs, and output

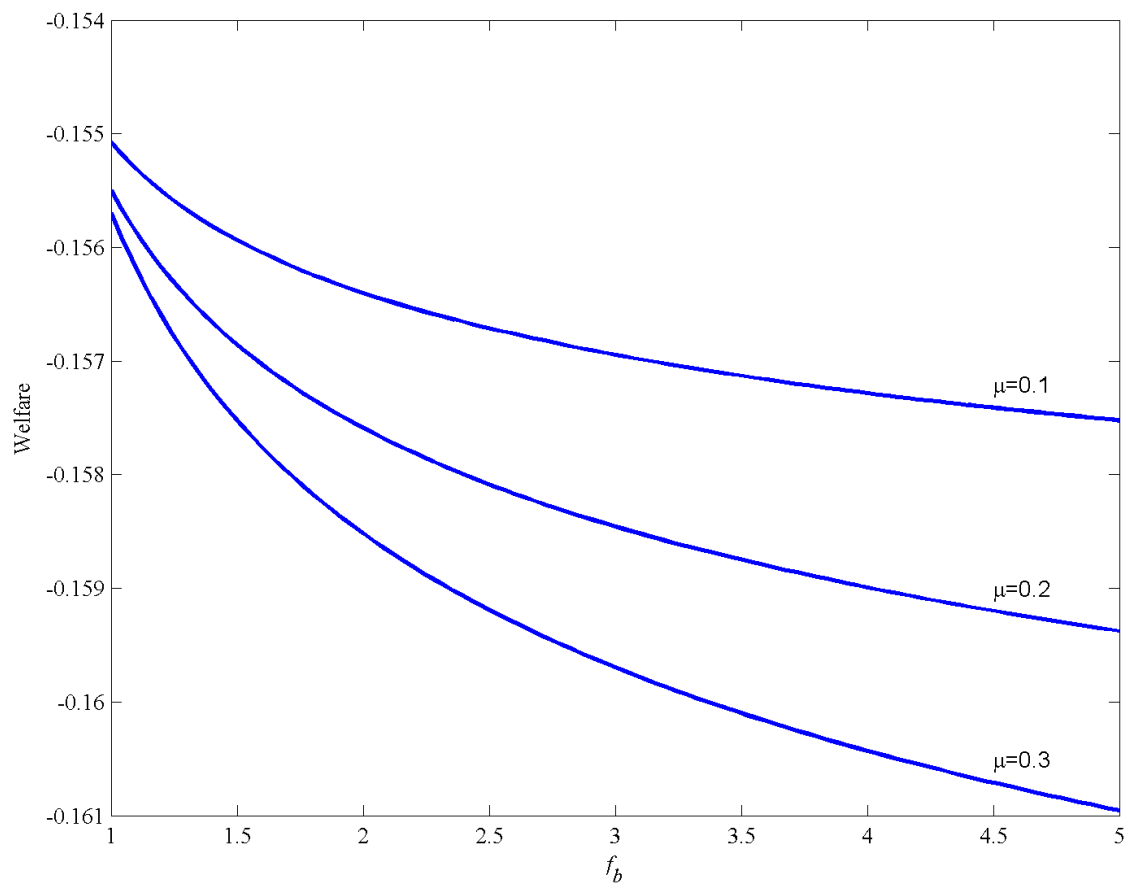

(b) Issuance costs, monitoring costs, and welfare

Figure 5: Aggregate outcomes from altering financial choice 


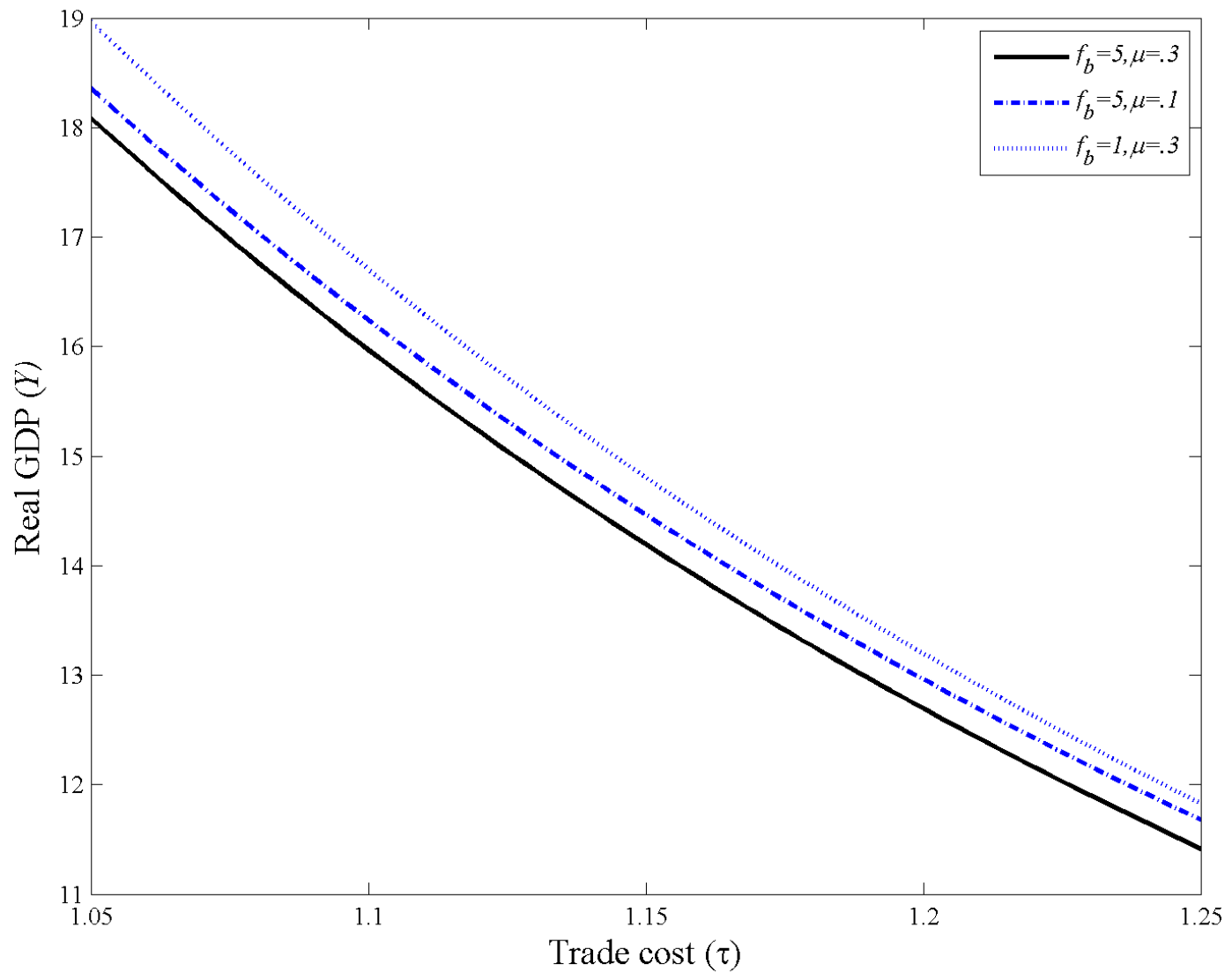

Figure 6: Aggregate output increases when trade costs fall 


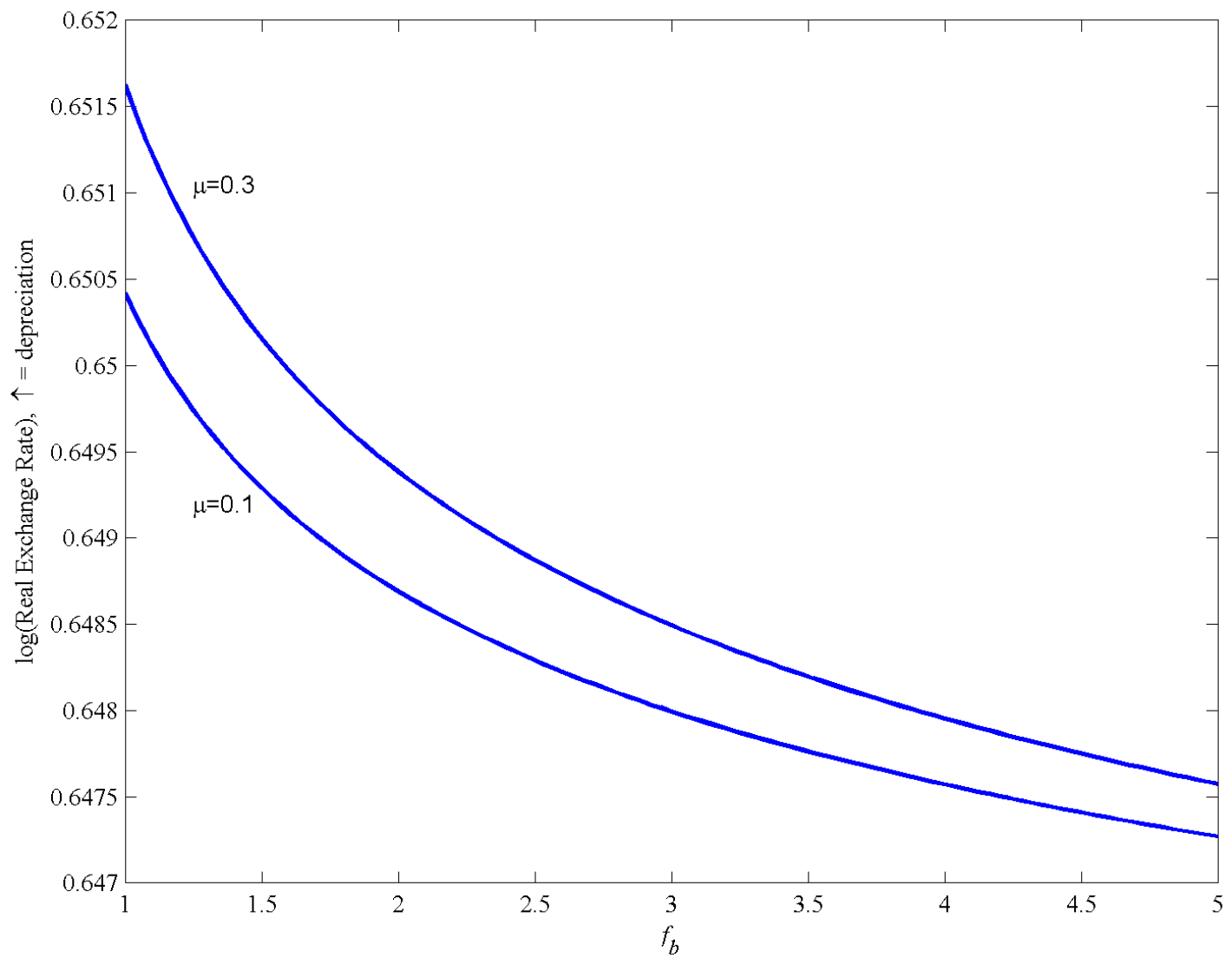

Figure 7: The real exchange rate depreciates as financial frictions decrease 


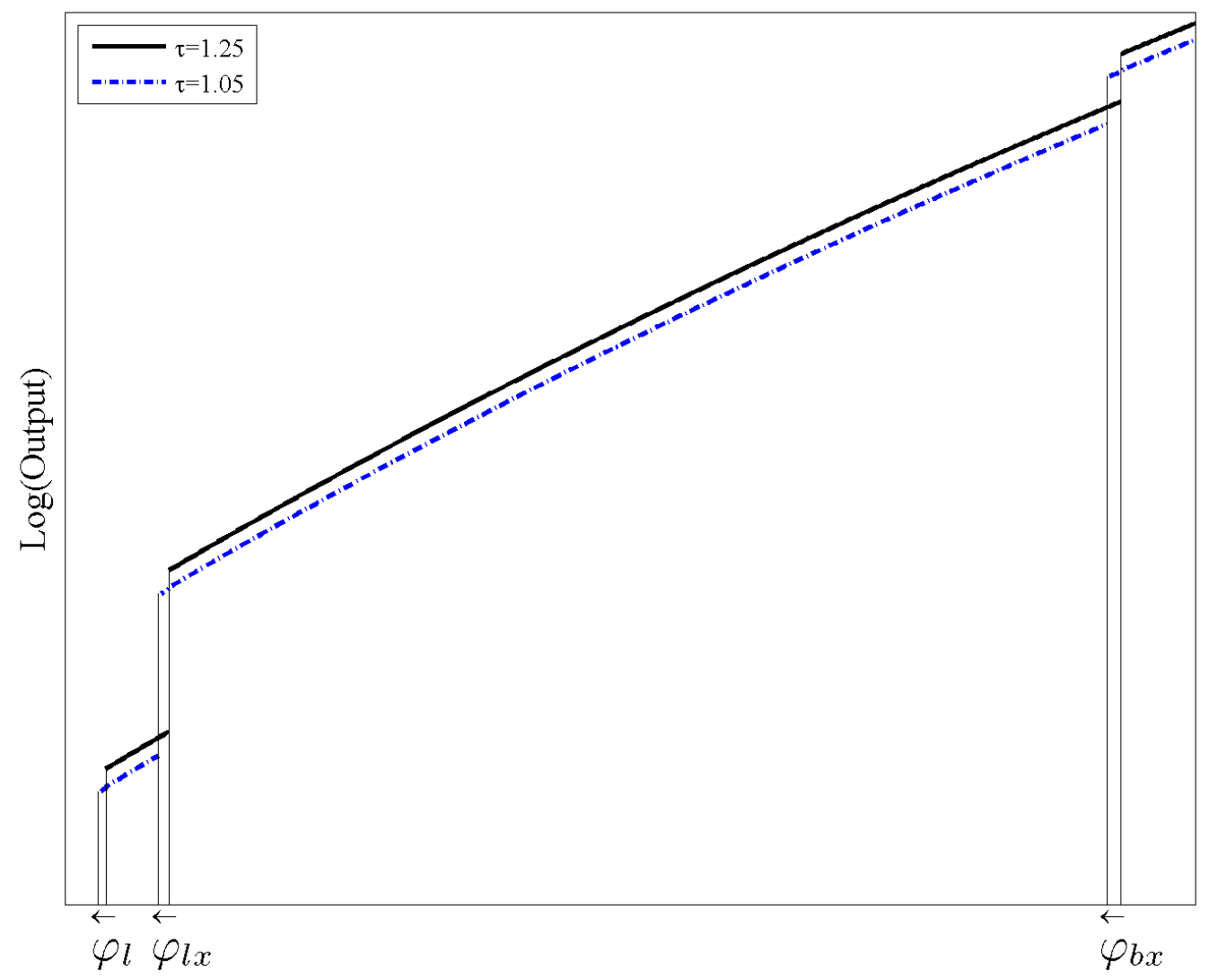

Figure 8: Output reallocated to switchers firms when trade costs fall 


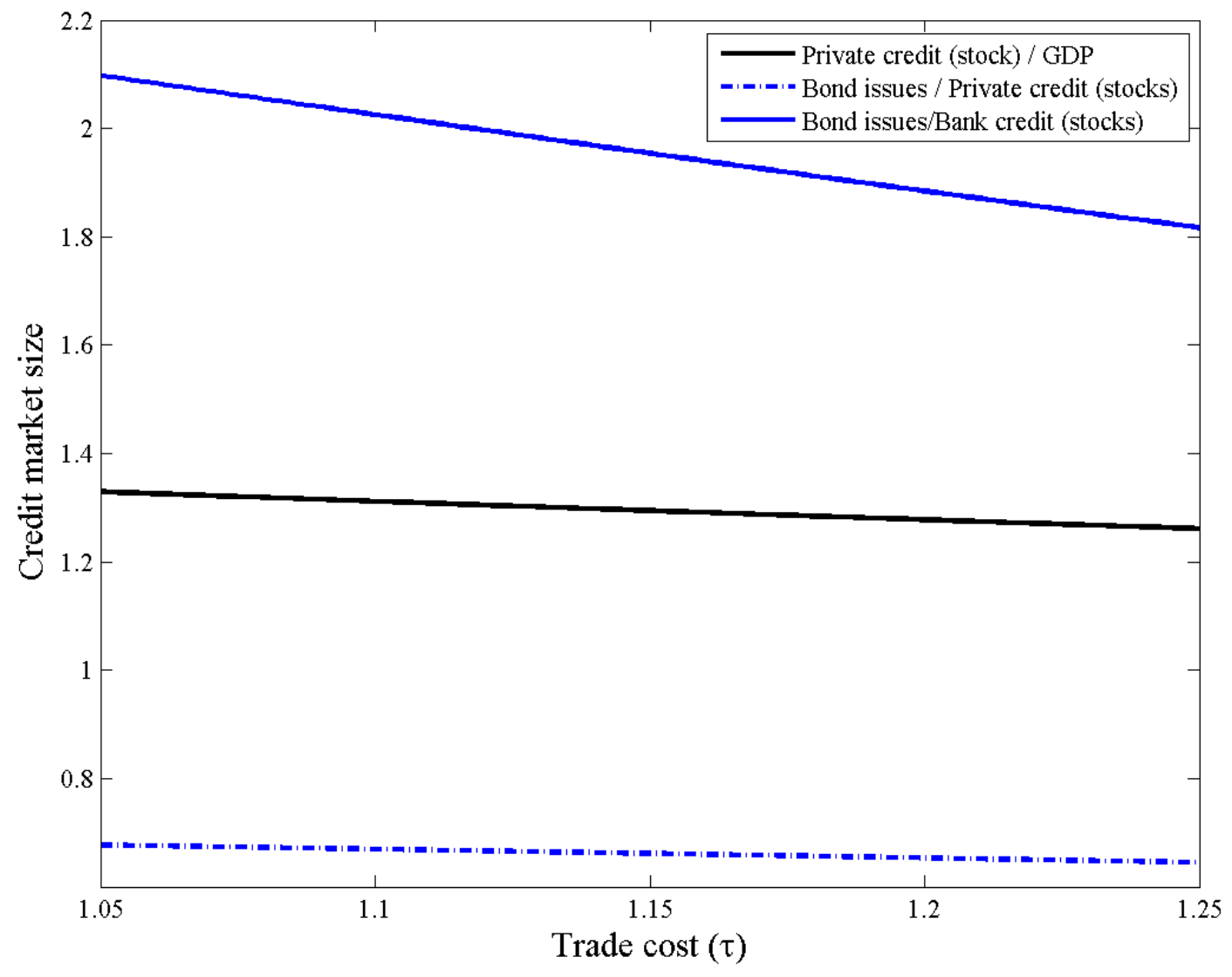

Figure 9: Trade liberalization causes growth in the relative size of the bond market 


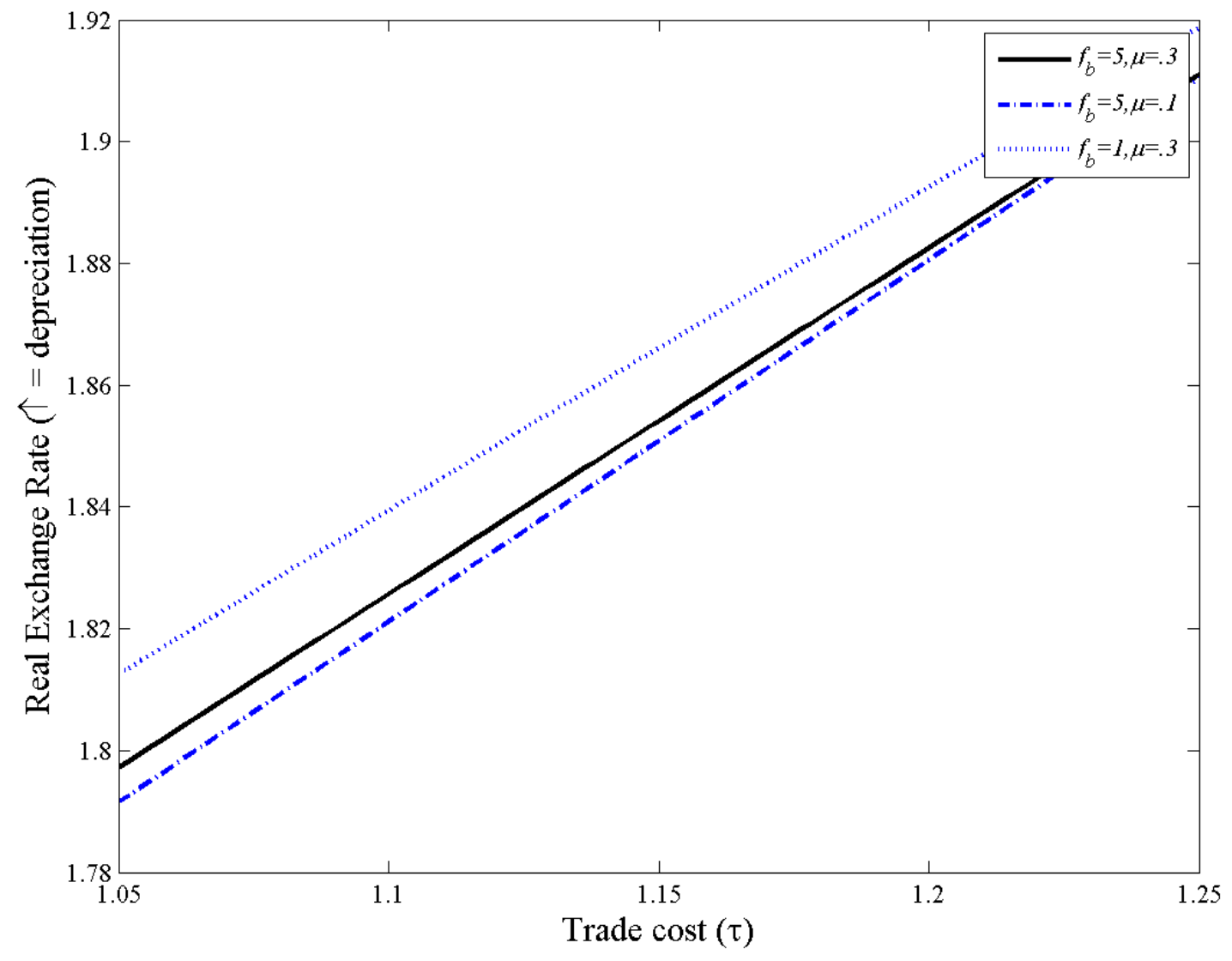

Figure 10: Trade liberalization causes real exchange rate appreciation 